\title{
Impaired Cholinergic Excitation of Prefrontal Attention Circuitry in the TgCRND8 Model of Alzheimer's Disease
}

\author{
Éliane Proulx, ${ }^{1}$ Paul Fraser, ${ }^{2,6}$ JoAnne McLaurin, ${ }^{5,7}$ and ${ }^{\circledR E v e l y n ~ K . ~ L a m b e ~}{ }^{1,3,4}$ \\ Departments of ${ }^{1}$ Physiology, ${ }^{2}$ Medical Biophysics, ${ }^{3}$ Obstetrics and Gynaecology, ${ }^{4}$ Psychiatry, and ${ }^{5}$ Laboratory Medicine and Pathobiology, ${ }^{6}$ Tanz Centre for \\ Research in Neurodegenerative Diseases, and `Biological Sciences, Sunnybrook Research Institute, University of Toronto, Toronto, Ontario M5S 1A8, Canada
}

Attention deficits in Alzheimer's disease can exacerbate its other cognitive symptoms, yet relevant disruptions of key prefrontal circuitry are not well understood. Here, in the TgCRND8 mouse model of this neurological disorder, we demonstrate and characterize a disruption of cholinergic excitation in the major corticothalamic layer of the prefrontal cortex, in which modulation by acetylcholine is essential for optimal attentional function. Using electrophysiology with concurrent multiphoton imaging, we show that layer 6 pyramidal cells are unable to sustain cholinergic excitation to the same extent as their nontransgenic littermate controls, as a result of the excessive activation of calcium-activated hyperpolarizing conductances. We report that cholinergic excitation can be improved in TgCRND8 cortex by pharmacological blockade of SK channels, suggesting a novel target for the treatment of cognitive dysfunction in Alzheimer's disease.

Key words: acetylcholine receptors; afterhyperpolarization potential (AHP); Alzheimer's model; corticothalamic; prefrontal cortex; SK channels

Significance Statement

Alzheimer's disease is accompanied by attention deficits that exacerbate its other cognitive symptoms. In brain slices of a mouse model of this neurological disorder, we demonstrate, characterize, and rescue impaired cholinergic excitation of neurons essential for optimal attentional performance. In particular, we show that the excessive activation of a calcium-activated potassium conductance disrupts the acetylcholine excitation of prefrontal layer 6 pyramidal neurons and that its blockade normalizes responses. These findings point to a novel potential target for the treatment of cognitive dysfunction in Alzheimer's disease.

\section{Introduction}

Alzheimer's disease (AD) is a neurodegenerative disorder that constitutes the main cause of dementia. It is associated with profound cognitive impairments that include severe memory loss and early attention deficits (Grady et al., 1988; Perry and Hodges, 1999; Baddeley et al., 2001; Romberg et al., 2013a). Impaired attention negatively affects the day-to-day life of $\mathrm{AD}$ patients, contributing to distraction, confusion, and poor executive control (Perry and Hodges, 1999). It is likely that disruptions in attention further exacerbate the memory deficits that constitute a telltale sign of the disease: if you can't attend, you can't encode (Romberg et al., 2013a,b). However, little is under-

Received Oct. 27, 2014; revised Aug. 1, 2015; accepted Aug. 9, 2015.

Author contributions: E.P. and E.K.L. designed research; E.P. performed research; P.F. and J.M. contributed unpublished reagents/analytic tools; E.P. and E.K.L. analyzed data; E.P., P.F., J.M., and E.K.L. wrote the paper.

This work was funded by Canadian Institutes of Health Research Grants MOP-89825 (E.K.L.), TAD-117950 (P.F.), and MOP-102467 (J.M.), the Canada Research Chairs Program (E.K.L.), an Ontario Early Researcher Award (E.K.L.), the Canadian Foundation for Innovation (E.K.L.), the Alzheimer's Society of Ontario (P.F.), and the Cryptic Rite Charitable Foundation (J.M.). We thank Mary Hill and Rosemary Ahrens for expert technical assistance.

Correspondence should be addressed to Dr. Evelyn K. Lambe, Department of Physiology, University of Toronto, 1 King's College Circle, Toronto, Ontario M5S 1A8, Canada. E-mail: evelyn.lambe@utoronto.ca.

DOI:10.1523/JNEUROSCI.4501-14.2015

Copyright $\odot 2015$ the authors $\quad 0270-6474 / 15 / 3512779-13 \$ 15.00 / 0$ stood of the cellular mechanisms that underlie the nonmnemonic deficits of executive function in $\mathrm{AD}$ and their contribution to the disease.

To date, acetylcholinesterase inhibitors constitute the standard of care for AD (Citron, 2010), although loss of cholinergic cells is an end-stage manifestation of the disease that is unlikely to account for cognitive deficits that may arise much earlier (Davis et al., 1999; Terry and Buccafusco, 2003). We now know that the cholinergic modulation of the prefrontal cortex (PFC) is essential for optimal attentional performance (Dalley et al., 2004; Parikh et al., 2007; Bailey et al., 2010; Guillem et al., 2011; Proulx et al., 2014a). Acetylcholine (ACh) is released in the PFC during attention tasks (Parikh et al., 2007), in which it exerts robust direct excitation of the deep cortical layers (Kassam et al., 2008; Poorthuis et al., 2013; Proulx et al., 2014b). The powerful and prolonged activation of layer 6 pyramidal neurons by $\mathrm{ACh}$ is consistent with the sustained firing necessary for attention and other executive functions (Funahashi et al., 1989; Hasselmo and Sarter, 2011; Ikkai and Curtis, 2011; Zhou et al., 2011) and depends on a complex interplay of nicotinic- and muscarinicmediated signaling (Bailey et al., 2010; Tian et al., 2011). Manifestations of $\mathrm{AD}$ in people and animal models have long 
Table 1. Electrophysiological properties of PFC layer 6 pyramidal neurons of TgCRND8 mice and littermate WT controls

\begin{tabular}{lccc}
\hline & WT & TgCRND8 & $P$ \\
\hline Capacitance (pF) & $72 \pm 2$ & $71 \pm 2$ & 0.5 \\
Input resistance $(\mathrm{M} \Omega)$ & $313 \pm 18$ & $285 \pm 16$ & 0.2 \\
Membrane potential $(\mathrm{mV})$ & $-83 \pm 1$ & $-85 \pm 1$ & 0.3 \\
Spike threshold $(\mathrm{mV})$ & $-52 \pm 0.4$ & $-51 \pm 0.5$ & 0.4 \\
Spike amplitude $(\mathrm{mV})$ & $79 \pm 1$ & $80 \pm 1$ & 0.5 \\
\hline
\end{tabular}

been linked to aberrations in cholinergic enzymatic activity (Davies and Maloney, 1976; Perry et al., 1978; Henke and Lang, 1983; Zubenko et al., 1989; Davis et al., 1999; Selkoe, 2001; Auld et al., 2002; DeKosky et al., 2002), nicotinic receptor binding (Nordberg et al., 1988; Whitehouse et al., 1988; Marutle et al., 1999; Nordberg, 2001; O'Brien et al., 2007; Kendziorra et al., 2011), and cholinergic signaling pathways (Kelly et al., 1996; Jope et al., 1997; Jope, 1999; Liu et al., 2001; Pettit et al., 2001; Auld et al., 2002). How do these broad changes affect the activation and sustained firing of prefrontal layer 6 attention circuitry?

To address this question, we examined cholinergic signaling in prefrontal attention circuitry of a well characterized animal model of AD. The TgCRND8 mouse model is used widely in Alzheimer's research and encodes both the Swedish and Indiana mutations of amyloid precursor protein (APP) found in inherited familial AD (Chishti et al., 2001). Here, we report significant impairments in the cholinergic excitation of layer 6 prefrontal neurons of TgCRND8 mice by 3-4 months of age and show that these deficits can be rescued pharmacologically.

\section{Materials and Methods}

Animals. All experiments were approved by the University of Toronto Animal Care Committee. We used adult male and female TgCRND8 mice on a mixed C57BL/6-C3H background, as reported previously (Chishti et al., 2001), along with their nontransgenic littermate siblings [wild type (WT)] as controls (mean \pm SEM age: WT, $109 \pm 2 \mathrm{~d}, n=20$ animals; TgCRND8, $109 \pm 2 \mathrm{~d}, n=26$ animals).

Brain slice preparation and recording conditions. Each brain was cooled as rapidly as possible with $4^{\circ} \mathrm{C}$ oxygenated sucrose artificial CSF (ACSF; $254 \mathrm{~mm}$ sucrose substituted for $\mathrm{NaCl}$ ). Coronal slices ( $400 \mu \mathrm{m}$ thick) of the PFC were cut on a Dosaka Pro-7 Linear Slicer (SciMedia) and were transferred to $30^{\circ} \mathrm{C}$ oxygenated ACSF (in mM: $128 \mathrm{NaCl}, 10$ D-glucose, 26 $\mathrm{NaHCO}_{3}, 2 \mathrm{CaCl}_{2}, 2 \mathrm{MgSO}_{4}, 3 \mathrm{KCl}$, and $\left.1.25 \mathrm{NaH}_{2} \mathrm{PO}_{4}, \mathrm{pH} 7.4\right)$ in a prechamber (Automate Scientific) and allowed to recover for at least $1.5 \mathrm{~h}$ before the beginning of an experiment. Slices were placed in a chamber on the stage of an upright microscope for whole-cell recordings. ACSF was bubbled with $95 \%$ oxygen and $5 \%$ carbon dioxide and flowed over the slice at $30^{\circ} \mathrm{C}$ with a rate of $3-4 \mathrm{ml} / \mathrm{min}$.

Electrophysiological recordings. Layer 6 pyramidal neurons were patched under visual control using infrared differential interference contrast microscopy in the cingulate and prelimbic regions of the PFC. Intracellular patch solution contained the following (in $\mathrm{mM}$ ): 120 K-gluconate, $5 \mathrm{KCl}, 2 \mathrm{MgCl}_{2}, 4 \mathrm{~K}$-ATP, $0.4 \mathrm{Na}_{2}$-GTP, $10 \mathrm{Na}_{2}$ phosphocreatine, and 10 HEPES buffer, adjusted to $\mathrm{pH} 7.33$ with $\mathrm{KOH}$. Data were acquired and low-pass filtered at $20 \mathrm{kHz}$ with an Axopatch 200b amplifier (Molecular Devices) and Digidata1440 digitizer/ pClamp10.2 software (Molecular Devices). Intrinsic cellular properties were assessed in current-clamp mode and did not differ significantly between genotypes (Table 1 ; mean \pm SEM; sample size for this analysis, $n=49$ WT neurons; $n=58$ TgCRND8 neurons).

All drugs were bath applied. ACh chloride and atropine were obtained from Sigma, apamin from Alomone Labs, dihydro- $\beta$-erythroidine hydrobromide (DH $\beta E$ ) and AP-5 from R\&D Systems, and cadmium chloride from Emerald BioSystems.

Calcium imaging. The calcium dye Oregon Green BAPTA-1 (OGB-1; $100 \mu \mathrm{M}$ ) was included in the pipette in a subset of cells, along with Alexa Fluor-594 hydrazide $(20 \mu \mathrm{M})$, to aid in the visualization of the neuron. Multiphoton imaging was performed using a titanium: sapphire laser (Newport) tuned to wavelength $800 \mathrm{~nm}$ and an Olympus Fluoview FV1000 microscope with a $60 \times$ water-immersion 0.90 numerical aperture objective. The emitted fluorescence was separated into green (OGB-1 signal) and red (Alexa Fluor-594 signal) channels with a dichroic mirror at $570 \mathrm{~nm}$ and filtered (green, barrier filter 495-540; red, barrier filter 570-620) before detection. Images were acquired at a rate of $\sim 10 \mathrm{frames} / \mathrm{s}$ and analyzed with Fluoview software. A pan-somatic area of interest was selected for analysis, and green fluorescence increases were calculated relative to baseline fluorescence $(d F / F)$. The green/red fluorescence $(\mathrm{G} / \mathrm{R})$ ratio was calculated by dividing the green signal by that of the red channel for the purpose of evaluating potential differences in basal calcium levels between genotypes.

Statistical analyses. Results are expressed as mean \pm SEM, and all statistical comparisons were made at a significance level of 0.05 (Prism versions 5.0d/6.0; GraphPad Software). Average traces of postburst potentials and fluorescent increases were generated with Axograph X. For the purpose of quantifying ACh-elicited firing, input-output curves and postburst afterhyperpolarization potentials (AHPs), action potentials were detected automatically with a derivative threshold of $20 \mathrm{mV} / \mathrm{ms}$. To assess the ability of cells to sustain near-maximal firing in response to $\mathrm{ACh}$, the cumulative probability of the instantaneous firing frequency of individual action potentials was normalized to the maximum instantaneous firing frequency within each ACh-elicited train of action potentials. By normalizing to maximum instantaneous frequency within the cell, neurons with a greater number of spikes will not unduly skew the cumulative probability distribution. This analysis further provides insight about the extent to which each spike train can sustain nearmaximal firing. Genotype and treatment differences of cumulative probabilities were assessed with Kolmogorov-Smirnov (K-S) tests. The peak and area under the curve (AUC) of postburst potentials were measured from the peak of the last action potential in each burst up to $1 \mathrm{~s}$ post-burst.

\section{Results}

\section{TgCRND8 mice cannot sustain peak excitation by ACh in} prefrontal layer 6

Because there is a panoply of cholinergic-related deficits in $\mathrm{AD}$, we investigated the effects of known concentrations of bathapplied ACh on brain slices from littermate WT and TgCRND8 mice at an age when attention deficits may be developing. In layer 6 pyramidal neurons of the PFC, ACh elicited cellular depolarization in a concentration-dependent manner in both WT and TgCRND8 mice (Fig. 1). Spiking was elicited in fewer cells in TgCRND8 than WT mice (Fig. 1A; three-way contingency test, $\left.G_{\mathrm{df}=7}^{2}=70.72, p<0.0001\right)$. Furthermore, in cells in which ACh ( $1 \mathrm{~mm}$ ) elicited suprathreshold depolarizations, ACh-elicited firing patterns were revealed to be distinct. The distribution of instantaneous frequency measurements for individual action potentials were significantly different between groups (Fig. 1B; $p<0.004$, Mann-Whitney test), and individual TgCRND8 neurons failed to sustain near-maximal firing frequencies to the same extent as WT cells (Fig. 1C): the cumulative probability of action potential frequency - normalized to maximal instantaneous frequency within each cell-was reduced dramatically in TgCRND8 neurons ( $\mathrm{K}-\mathrm{S}$ test, $p<0.00001)$. However, the maximal instantaneous firing frequency (WT, $9 \pm 1 \mathrm{~Hz}, n=17$; TgCRND8, $11 \pm$ $3 \mathrm{~Hz}, n=15$; $t$ test, $p=0.4$ ) and duration of spiking (WT, $47 \pm$ $11 \mathrm{~s}, n=17$; TgCRND8, $42 \pm 9 \mathrm{~s}, n=15$; $t$ test, $p=0.7$ ) achieved were similar between genotypes. The depolarization elicited by ACh was not significantly different between genotypes as revealed by two-way repeated-measures ANOVA (Fig. 1D; effect of genotype, $\left.F_{(1,40)}=0.29, p=0.6\right)$. Additional probes of the elec- 
A

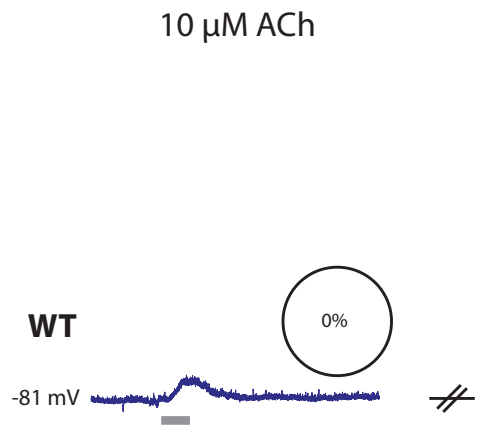

$100 \mu \mathrm{M} \mathrm{ACh}$

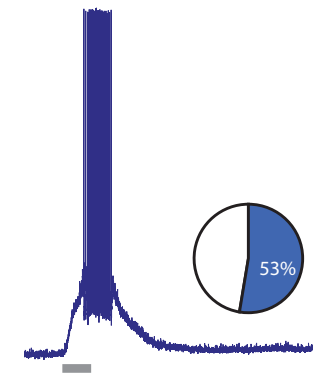

$1 \mathrm{mM} \mathrm{ACh}$

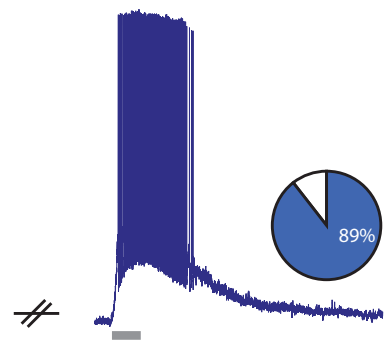

TgCRND8

$-82 \mathrm{mV}$



H

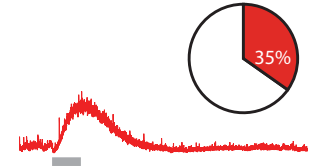

B

$\underline{\text { ACh-elicited firing (1 mM) }}$
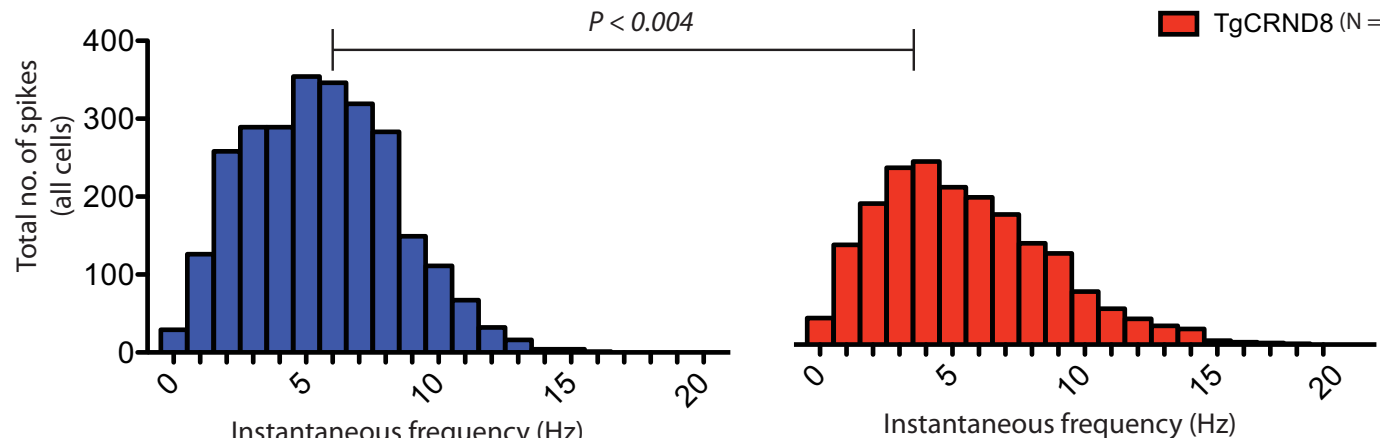

Instantaneous frequency $(\mathrm{Hz})$

C
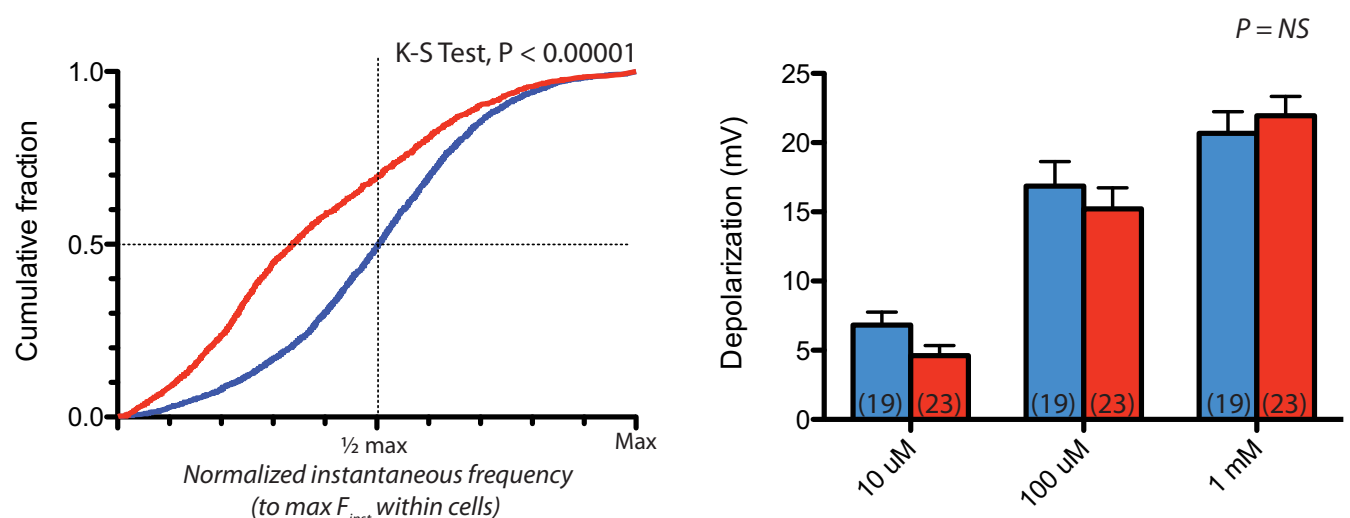

Figure 1. Impaired excitation in response to ACh in layer 6 PFC of TgCRND8 mice. Bath application of ACh elicits cellular depolarization from resting membrane potential in a concentrationdependent manner in both WT and TgCRND8 neurons. ACh was applied at $10 \mu \mathrm{m}, 100 \mu \mathrm{m}$, and $1 \mathrm{~mm}$ in WT ( $n=19$ matched pairs) and TgCRND8 ( $n=23$ matched pairs). $A$, Representative example of responses in a WT cell (top, blue traces) and a TgCRND8 neuron (bottom, red traces). Pie charts depict the proportion of cells in which ACh elicited depolarizations that led to spiking. ACh elicited spiking in 0 of 19 cells in WT and 0 of 23 cells in TgCRND8 when applied at $10 \mu \mathrm{m}$, in 10 of $19(53 \%)$ cells in WT and 8 of 23 (35\%) cells in TgCRND8 at $100 \mu \mathrm{M}$, and in 17 of 19 (89\%) cells in WT and 15 of $23(65 \%)$ cells in TgCRND8 mice when applied at $1 \mathrm{~mm}$ (three-way contingency test, $G_{\mathrm{df}=7}^{2}=70.72, p<0.0001$ ). $\boldsymbol{B}$, Frequency histograms of instantaneous firing frequencies elicited by ACh $(1 \mathrm{~mm})$ in all cells $\left(p<0.004\right.$, Mann-Whitney test). C, The cumulative probability of action potential firing frequency elicited by $1 \mathrm{~mm} A \mathrm{ACh}$ [normalized to maximal instantaneous frequency $\left(\mathrm{F}_{\text {inst }}\right)$ within each cell] reveals that TgCRND8 neurons fail to sustain near maximal firing frequencies to the same extent as WT cells ( $\mathrm{K}-\mathrm{S}$ test, $p<0.00001)$. Note that the distribution is left-skewed in TgCRND8 neurons, with a greater number of observations falling below half-maximal frequency values. D, Mean depolarization was $7 \pm 1 \mathrm{mV}$ in WT and $5 \pm 1 \mathrm{mV}$ in TgCRND8 at $10 \mu \mathrm{M}, 17 \pm 2$ $\mathrm{mV}$ in WT and $15 \pm 2 \mathrm{mV}$ in TgCRND8 at $100 \mu \mathrm{m}$, and $21 \pm 2 \mathrm{mV}$ in WT and $22 \pm 1 \mathrm{mV}$ in TgCRND8 at $1 \mathrm{~mm}$ ACh. The depolarization achieved was not significantly different between genotypes as revealed by two-way repeated-measures ANOVA (effect of genotype, $F_{(1,40)}=0.29, p=0.6$ ). 

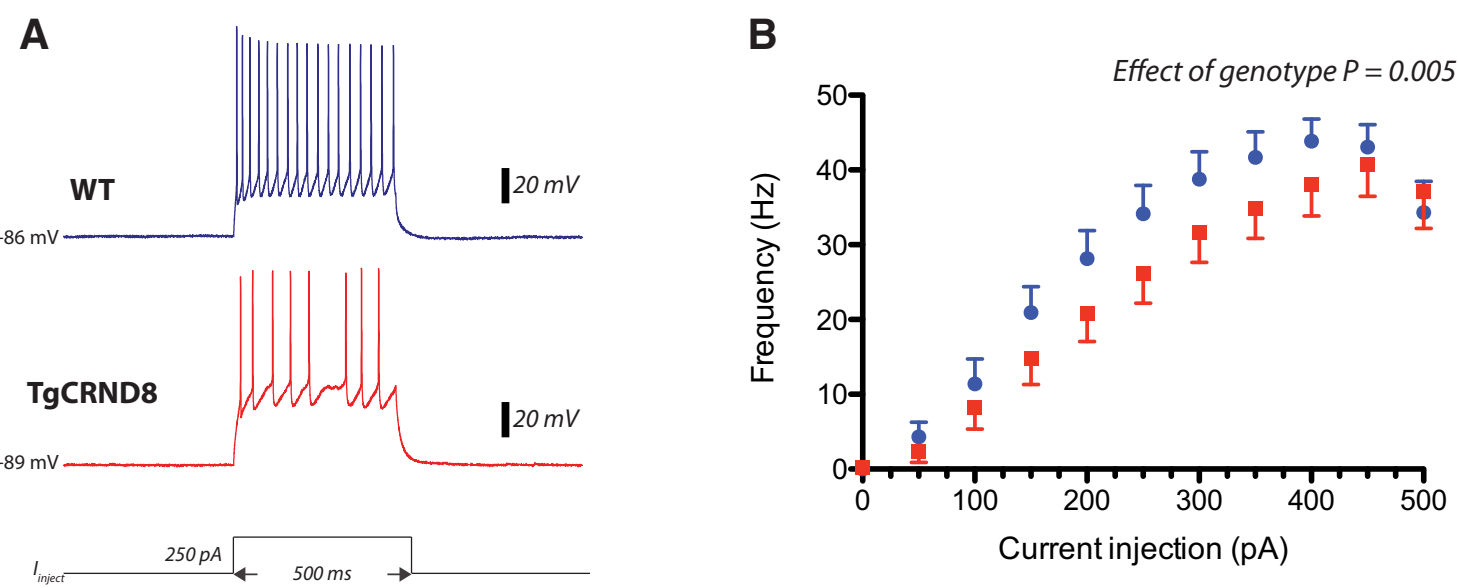

Figure 2. Reduced intrinsic excitability in layer 6 prefrontal pyramidal neurons of TgCRND8 mice. Input- output curves were generated by applying depolarizing current steps of $500 \mathrm{~ms}$ duration in $50 \mathrm{pA}$ increments from resting membrane potential. $A$, Representative example of a train of action potentials elicited by a $250 \mathrm{pA}$ current step in WT (top, blue trace) and TgCRND8 (bottom, red trace) neurons. Bottom, A schematic representation of the current injection. $\boldsymbol{B}$, Input- output curves in WT cells (blue, $n=13$ ) and $\operatorname{TgCRND8}$ cells (red, $n=12$ cells). Data points represent mean \pm SEM. Effect of genotype is significant as revealed by two-way ANOVA $\left(F_{(1,253)}=8.12, p=0.005\right)$.

trophysiological effects of ACh in layer 6 pyramidal cells in voltage clamp found that, near resting membrane potential $\left(V_{\text {hold }}=\right.$ $-75 \mathrm{mV})$, ACh currents were modestly but significantly smaller in TgCRND8 mice (WT, $-121 \pm 8 \mathrm{pA}, n=23$; TgCRND8, $-92 \pm 9 \mathrm{pA}, n=28 ; p=0.02)$. However, pharmacological dissection of these current revealed similar nicotinic $\left(\mathrm{WT}_{\text {atropine, }}\right.$ $\left.-83 \pm 12 \mathrm{pA}, n=7 ; \mathrm{TgCRND}_{\text {atropine }},-86 \pm 12 \mathrm{pA}, n=9 ; p=0.9\right)$ and muscarinic $\left(\mathrm{WT}_{\mathrm{DHBE}},-33 \pm 7 \mathrm{pA}, n=8\right.$; TgCRND $8_{\mathrm{DHBE}}$, $-22 \pm 6 \mathrm{pA}, n=7 ; p=0.3$ ) contributions, suggesting that the ACh current may be decreased in the TgCRND8 mice through an interaction of nicotinic and muscarinic signaling. Therefore, to compensate for any potential differences in the cholinergic drive toward threshold between the genotypes, we applied current to the cells to elicit baseline firing at $1-3 \mathrm{~Hz}$. Under these conditions, TgCRND8 neurons also failed to achieve equivalent levels of peak firing (maximal instantaneous frequency: WT, $21 \pm 2 \mathrm{~Hz}, n=10$ cells; TgCRND8, $15 \pm 2 \mathrm{~Hz}$, $n=13$ cells; $p<0.05$; cumulative probability of action potential instantaneous frequencies, $\mathrm{K}-\mathrm{S}$ test, $p<0.00001$; data not shown). Altogether, these data suggest that the deficit in layer 6 neurons at this early stage in TgCRND8 mice appears to be selectively limited to a marked impairment in the ability to maintain peak excitation to ACh.

\section{Probing mechanisms of altered excitability in TgCRND8 prefrontal layer 6 neurons}

Given the observed differences in sustaining ACh-elicited peak firing, we investigated whether there were differences in intrinsic excitability in prefrontal layer 6 pyramidal neurons. We generated input-output curves by applying depolarizing current steps of $500 \mathrm{~ms}$ duration in $50 \mathrm{pA}$ increments. A clear difference between genotypes was evident in the layer 6 neurons at stronger depolarizations, with fewer action potentials elicited in TgCRND8 mice (Fig. 2; effect of genotype, two-way ANOVA, $\left.F_{(1,253)}=8.12, p=0.005\right)$. However, at rheobase, there were no significant differences in action potential amplitude (WT, $79 \pm 3$ $\mathrm{mV}, n=13$; TgCRND8, $77 \pm 2, n=12 ; p=0.5$ ), rise time (WT, $282 \pm 12 \mu \mathrm{s}, n=13$; TgCRND8, $289 \pm 11 \mu \mathrm{s}, n=12 ; p=0.7)$, half-width (WT, $1 \pm 0.03 \mathrm{~ms}, n=13$; TgCRND8, $1 \pm 0.03 \mathrm{~ms}$, $n=12 ; p=0.4$ ), or current applied (WT, $66 \pm 10 \mathrm{pA}, n=13$; TgCRND8, $84 \pm 11 \mathrm{pA}, n=12 ; p=0.2)$ in the same subset of cells.
The neuronal ability to sustain repetitive spike firing is dependent on the electrophysiological phenomenon known as the AHP (Kandel and Spencer, 1961; Sah, 1996; Disterhoft and Oh, 2006; Bean, 2007), which constitutes the undershoot of the action potential and results from hyperpolarizing conductances activated during spiking. Accordingly, we examined systematically whether there were genotype differences in the AHP that occurs in response to the identical numbers of action potentials in TgCRND8 cells and WT controls. Action potentials were elicited by applying brief depolarizing current pulses $(2 \mathrm{nA}, 2 \mathrm{~ms})$ at 50 $\mathrm{Hz}$ from a membrane potential of $-70 \mathrm{mV}$ (Fig. 3). Both the peak AHP and postburst area were significantly greater in TgCRND8 mice as revealed by two-way ANOVA (Fig. $3 B, C$; effect of genotype, peak AHP, $F_{(1,259)}=8.35, p=0.004$; postburst area, $F_{(1,222)}=$ $18.53, p<0.0001)$. A more detailed analysis further revealed that the greatest differences were observed between 100 and $500 \mathrm{~ms}$ after burst (data not shown), suggesting differences in what is considered the medium AHP (Sah, 1996; Faber and Sah, 2003).

Because several components of the AHP exhibit calcium dependence (Sah, 1996; Faber and Sah, 2003), we sought to determine whether enhanced postburst AHPs were correlated with increased calcium responses in layer 6 TgCRND8 neurons. Accordingly, this subset of our AHP experiments were performed with concurrent multiphoton imaging of the intracellular calcium indicator OGB-1 $(100 \mu \mathrm{M})$ in the recorded layer 6 pyramidal neurons. The spike burst protocols elicited changes in intracellular calcium levels, as measured by changes in fluorescence with respect to baseline levels $(d F / F)$. These changes depended on the number of spikes in both genotypes (effect of number of spikes, peak $d F / F, F_{(5,222)}=93.06, p<0.0001 ; d F / F$ area, $\left.F_{(5,122)}=80.48, p<0.0001\right)$ but were significantly greater in layer 6 TgCRND8 neurons (Fig. 4; peak $d F / F$, effect of genotype, $F_{(1,222)}=11.82, p=0.0007 ; d F / F$ area, effect of genotype, $F_{(1,122)}=$ $12.61, p=0.0005)$. Baseline fluorescence was not different between genotypes, as assessed by the G/R ratio (WT, $233 \pm 13$ units, $n=16$; TgCRND8, $230 \pm 15$ units, $n=23$; $p=0.9$ ). Moreover, the linear regression of mean peak AHP against mean peak $d F / F$ in WT and TgCRND8 neurons were similar between genotypes, suggesting that AHPs are enhanced in TgCRND8 mice as a result of enhanced calcium increases (slopes of the linear regressions, $p=0.2$ ). 


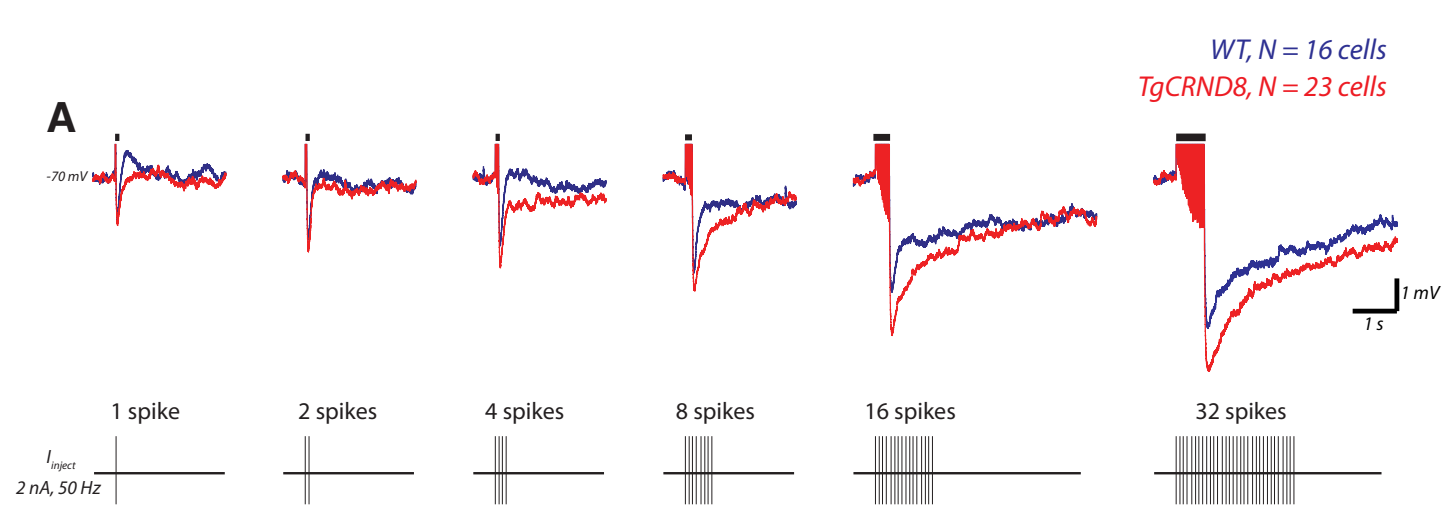

B

Peak AHP

C

Post-burst Area
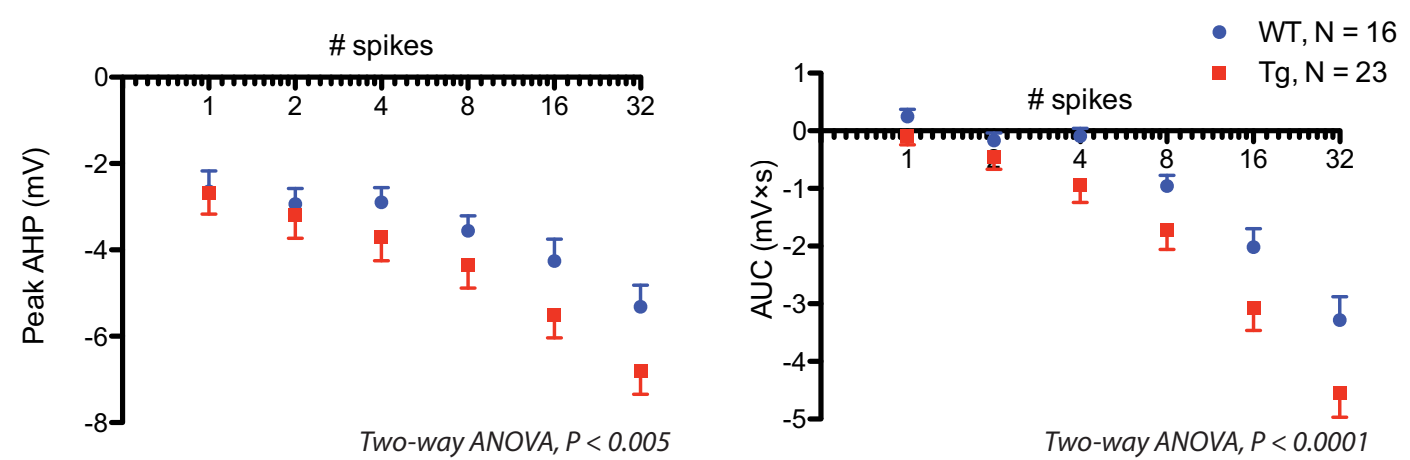

Figure 3. The AHP is enhanced in layer 6 pyramidal neurons of TgCRND8 mice. Action potentials were elicited by applying brief depolarizing current pulses ( $2 \mathrm{nA}, 2 \mathrm{~ms})$ at $50 \mathrm{~Hz}$ from a membrane potential of $-70 \mathrm{mV}$. $A$ depicts the overlay of the average responses in WT (blue, $n=16$ cells) and TgCRND8 (red, $n=23$ cells). A schematic of the spike burst protocol is shown below. $\boldsymbol{B}$, Peak AHP in WT and TgCRND8 (two-way ANOVA, effect of genotype, $F_{(1,259)}=8.35, p=0.004$ ). C, Mean postburst AUC in WT and TgCRND8 (two-way ANOVA, effect of genotype, $F_{(1,222)}=18.53, p<$ 0.0001). Data represented in $B$ and $($ are mean \pm SEM.

One candidate channel for a calcium-dependent medium AHP is the small-conductance calcium-activated potassium channel known as SK (Sah, 1996; Faber and Sah, 2003). We found that, in WT layer 6 PFC pyramidal neurons, the postburst AHP was reduced by the SK-specific toxin apamin, particularly between 50 and $100 \mathrm{~ms}$ after the burst (Fig. 5). In TgCRND8 layer 6 neurons, the postburst AHP was also reduced by apamin $\left(\right.$ TgCRND $8_{\text {control }}$ vs TgCRND8 ${ }_{\text {apamin }}$, peak AHP, $F_{(1,258)}=39.14$, $p<0.0001$; AUC, $\left.F_{(1,258)}=33.59, p<0.0001\right)$. Moreover, between 100 and $500 \mathrm{~ms}$ - at which the genotype difference was most pronounced - differences were abolished in the presence of apamin (Fig. 6; $\mathrm{WT}_{\text {apamin }}$ vs TgCRND8 $8_{\text {apamin }}$, peak $\mathrm{AHP}_{100-500 \mathrm{~ms}}$, $\left.F_{(1,234)}=0.04, p=0.84 ; \mathrm{AUC}_{100-500 \mathrm{~ms}}, F_{(1,234)}=0.40, p=0.53\right)$, suggesting that the enhanced AHPs in TgCRND8 mice result from a greater SK contribution. Interestingly, the apamin experiments did reveal a residual, apamin-resistant early AHP in TgCRND8 neurons (one to four spikes). Overall, however, the SK inhibitor apamin restored AHP area to WT control levels in TgCRND8 neurons ( $\mathrm{WT}_{\text {control }}$ vs TgCRND8 $8_{\text {apamin }}$, two-way ANOVA, $\left.F_{(1,216)}=1.03, p=0.3\right)$ and also abolished genotype differences in intrinsic excitability as assessed by input-output curves $\left(\mathrm{WT}_{\text {control }}\right.$ vs TgCRND8 $8_{\text {apamin }}$, two-way ANOVA, $F_{(1,168)}=$ $0.01, p=0.9)$.

Enhanced suprathreshold calcium flux underlies aberrations in the cholinergic excitation of layer 6 pyramidal neurons of TgCRND8 animals

Cholinergic stimulation of layer 6 pyramidal neurons has the potential to raise intracellular calcium levels substantially. Not only does ACh bring the majority of these neurons to spikingthereby permitting the activation of voltage-sensitive channels that flux calcium (i.e., NMDA receptors, voltage-gated calcium channels) - but the ACh receptors themselves are poised to contribute to intracellular calcium increases. Indeed, in layer 6 PFC, ACh stimulates an unusual subtype of nicotinic receptor (Bailey et al., 2010) known to have high calcium flux (Tapia et al., 2007) and stimulates excitatory muscarinic receptors (Tian et al., 2011), which can also release calcium from intracellular stores in prefrontal neurons (Gulledge and Stuart, 2005; Gulledge et al., 2009; Proulx et al., 2014b). Thus, given the observation that cholinergic firing is impaired in TgCRND8 neurons and that calciumdependent AHPs are enhanced in these same cells, we next investigated whether ACh-elicited spiking is accompanied by greater calcium responses in the TgCRND8 neurons. ACh (1 mM, $15 \mathrm{~s})$ elicited spiking in eight of nine cells in WT and six of seven cells in TgCRND8 mice with calcium increases that were significantly greater in the TgCRND8, as detected by the calcium-sensitive dye OGB-1 (100 $\mu \mathrm{M}$; Fig. 7; peak dF/F: WT, $50 \pm 9 \%, n=8$; TgCRND8, $78 \pm 7 \%, n=6, p=0.04$; area of $d F / F:$ WT, $1090 \pm$ $240 \% \times \mathrm{s}, n=8, \mathrm{TgCRND} 8,1950 \pm 500 \% \times \mathrm{s}, n=6, p=0.1$ ). Furthermore, in this independent replication, we also observed that TgCRND8 cells failed to sustain firing frequencies to the same extent as WT neurons (cumulative probabilities of normalized instantaneous frequency, $\mathrm{K}-\mathrm{S}$ test, $p<0.00001$ ). Thus, impairments in cholinergic firing in the TgCRND8 neurons were accompanied by increased calcium responses.

Because multiple sources of calcium may contribute to these cholinergic calcium responses in layer 6 neurons of PFC, we ex- 


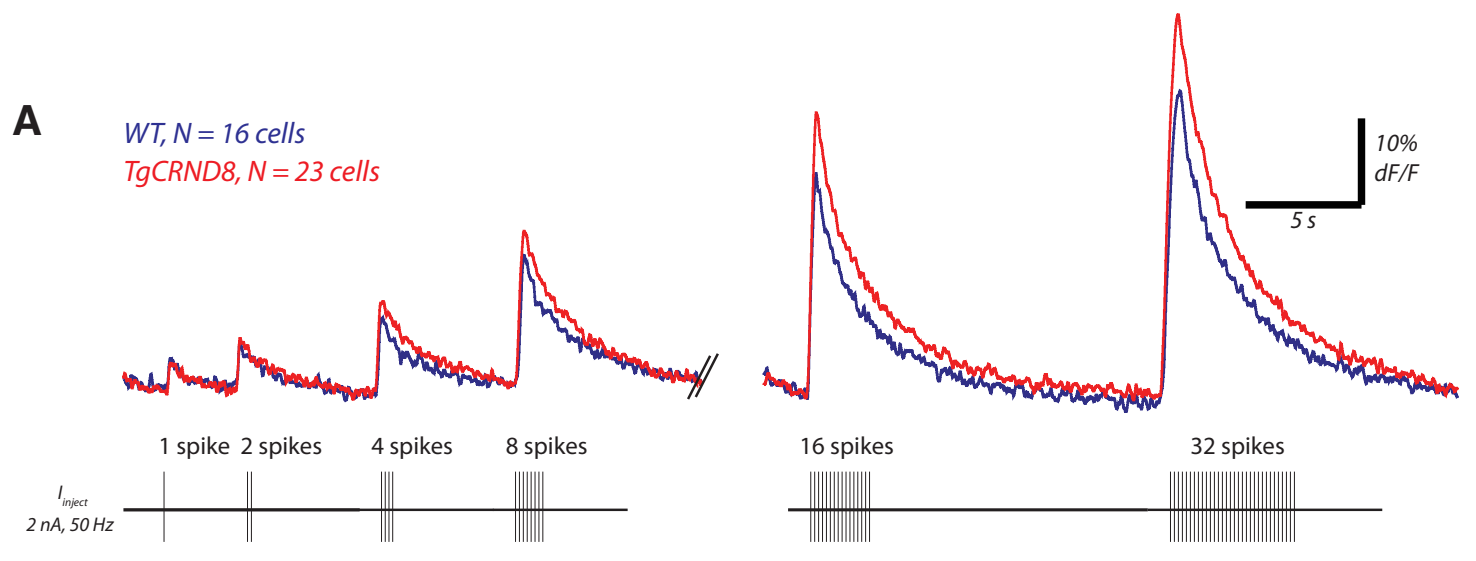

B

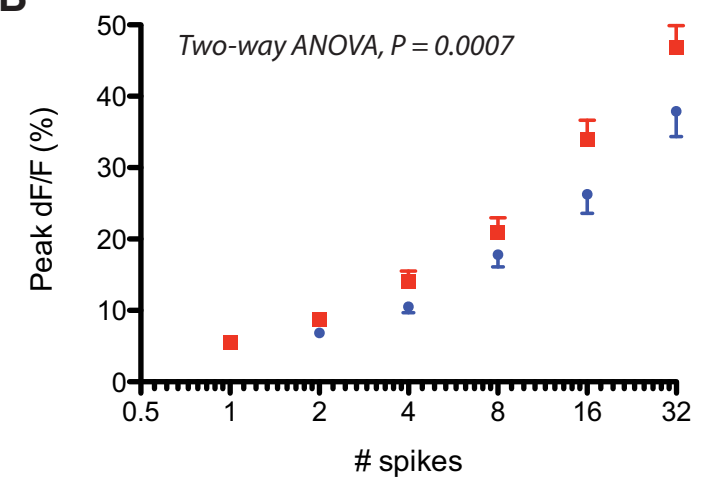

C

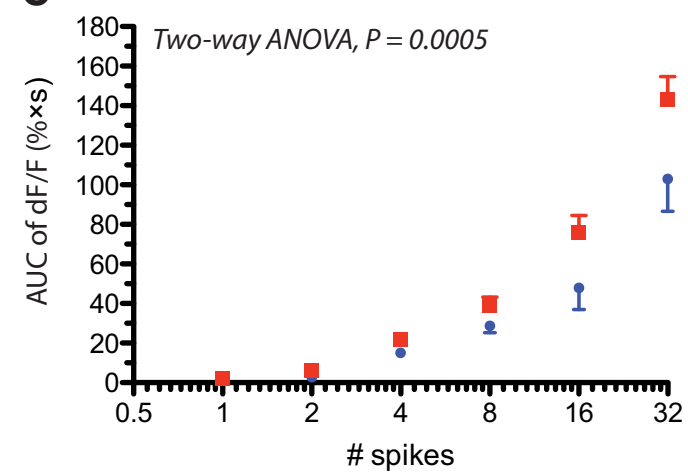

Figure 4. Spiking elicits greater $\mathrm{Ca}^{2+}$ responses in TgCRND8 neurons. $A$, In the same subset of cells as Figure 3, changes in calcium with respect to baseline levels (dF/F) elicited by the spike burst protocol detected by the calcium indicator OGB-1 (100 $\mu \mathrm{M}$ ) with two-photon microscopy. An overlay of the average responses in WT (blue, $n=16)$ and TgCRND8 (red, $n=23$ ) is shown, and a schematic of the spike burst protocol is depicted below. B, Quantification of the peak $\mathrm{F} / F$ (mean $\pm \mathrm{SEM}$ ) in WT and TgCRND8 neurons (two-way ANOVA, effect of genotype, $F_{(1,222)}=11.82, p=$ 0.0007). C, AUC of dF/F in WT and TgCRND8 (two-way ANOVA, effect of genotype, $F_{(1,122)}=12.61, p=0.0005$ ).

amined genotype differences in both subthreshold and suprathreshold sources of calcium ion flux. In voltage clamp, to prevent spiking and the opening of voltage-gated channels, calcium responses elicited by ACh were not different between genotypes when the membrane potential was clamped at $-75 \mathrm{mV}$ (peak $d F / F: \mathrm{WT}, 46 \pm 6 \%, n=16$; TgCRND8, $48 \pm 7 \%, n=18 ; p=0.8$; area of $d F / F$ : WT, $638 \pm 110 \% * s, n=16$; TgCRND8, $606 \pm 65 \%$ $* s, n=18, p=0.8)$. These data suggest that cholinergic stimulation greatly enhances cellular calcium increases in the TgCRND8 mice only when coincident with trains of action potentials. To probe these genotype differences in suprathreshold calcium influx, we next examined ACh calcium responses in current clamp in the presence of the NMDA receptor channel antagonist AP-5 $(50 \mu \mathrm{M})$ or in the presence of the voltage-gated calcium channel blocker $\mathrm{CdCl}_{2}(100 \mu \mathrm{M})$. We found that AChelicited calcium responses were significantly reduced with respect to ACSF control in the TgCRND8 neurons but not in WT cells, in either AP-5 (peak $d F / F$ : $\mathrm{WT}_{\mathrm{AP}-5}, 68 \pm 9, n=7, p=0.2$; TgCRND8 $\left.8_{\mathrm{AP}-5}, 38 \pm 7 \%, n=7, p=0.002\right)$ or $\mathrm{CdCl}_{2}$ (peak $d F / F$ : $\mathrm{WT}_{\mathrm{CdCl} 2}, 32 \pm 9 \%, n=5, p=0.2 ; \mathrm{Tg}_{\mathrm{CdCl} 2}, 15 \pm 4 \%, n=7, p<$ $0.0001)$. In addition, each manipulation could improve the ability of TgCRND8 neurons to sustain cholinergic firing (K-S tests, TgCRND8 $8_{\text {control }}$ vs TgCRND8 ${ }_{\text {AP5 }}, p<0.0005$; TgCRND8 $8_{\text {control }}$ Vs TgCRND8 $\left.8_{\mathrm{CdCl} 2}, p<0.00001\right)$, consistent with the interpretation that the dysregulation of a calcium-sensitive conductance underlies impairments in the cholinergic excitation of TgCRND8 neurons.
Inhibition of SK channels improves cholinergic excitability of TgCRND8 neurons

Because the layer 6 TgCRND8 neurons show reduced ability to maintain peak firing, elevated calcium levels in response to ACh, and enhanced apamin-sensitive AHPs, we sought to determine whether the inhibition of SK channels could help improve cholinergic excitability in layer 6 PFC of TgCRND8 mice. In the presence of apamin, an SK-antagonist, $1 \mathrm{~mm}$ ACh elicited spiking in 8 of $12(67 \%)$ cells, and, under these conditions, higherfrequency spiking could now be sustained to a significantly greater extent, leading to a rightward shift of the cumulative probability distribution of ACh-elicited firing frequency in TgCRND8 neurons (Fig. $8 B$; K-S test, $p<0.00001$ ). These data support strongly the hypothesis that impairments in cholinergic excitability arise from enhanced activity of calcium-activated SK channels in layer 6 of the TgCRND8 mice.

Together, our findings demonstrate early disruption of cholinergic excitation of layer 6 PFC neurons in an animal model of $\mathrm{AD}$, identify mechanisms underlying this disruption, and use this information to restore the maintenance of peak cholinergic excitability in a critical component of attention circuitry.

\section{Discussion}

We have found that layer 6 pyramidal neurons of the PFC are susceptible to disruptions of cellular excitability in the TgCRND8 brain. In particular, we show that these cells are unable to sustain cholinergic excitation to the same extent as nontransgenic litter- 
A
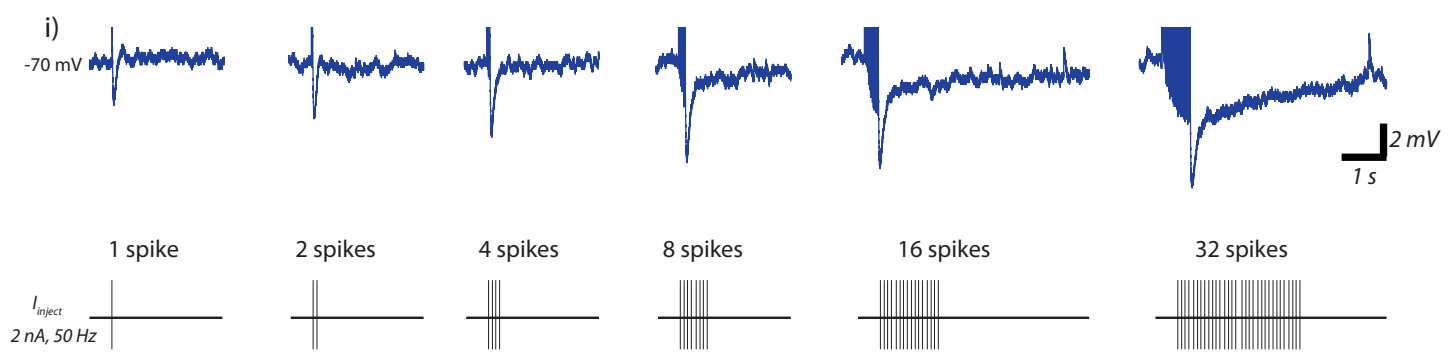

+200 nM apamin

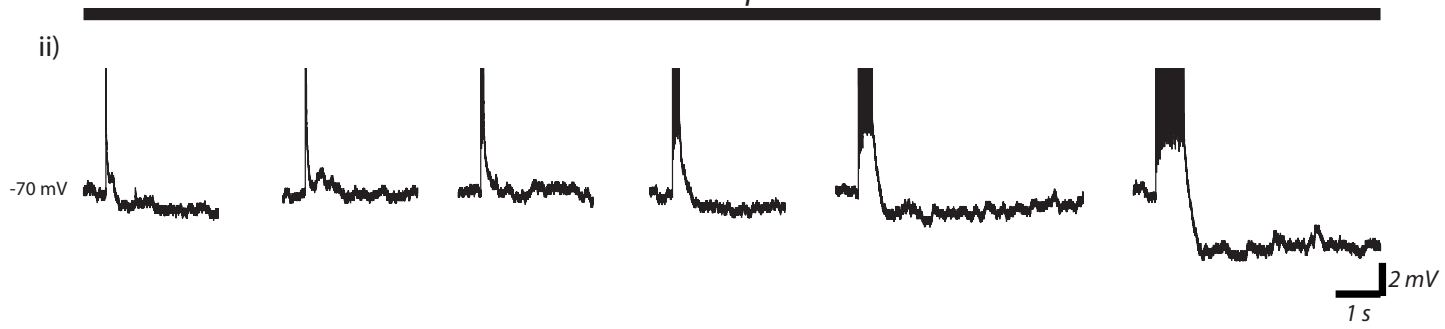

B

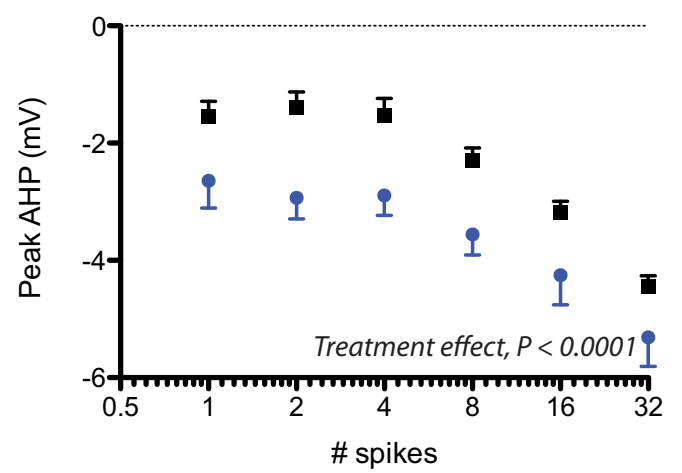

C

- $\mathrm{WT}$ control $(\mathrm{N}=16)$

- $\mathrm{WT}+\operatorname{Apamin}(\mathrm{N}=19)$

Figure 5. The postburst AHP is apamin sensitive in WT. $A$, An example of postburst AHPs elicited under control condition in WT and an example of postburst AHPs elicited in the presence of the SK antagonist apamin (200 nM) in another layer 6 PFC neuron from WT (bottom). $\boldsymbol{B}, \boldsymbol{C}$, In control versus apamin conditions, measurements of the peak AHP (two-way ANOVA, treatment effect, $F_{(1,198)}=39.62, p<0.0001$ ) and postburst area (two-way ANOVA, treatment effect, $\left.F_{(1,198)}=10.70, p=0.001\right)$.

mate mice as a result of the excessive activation of calciumactivated hyperpolarizing conductances. Cholinergic excitation can be improved in layer 6 pyramidal cells of TgCRND8 mice by pharmacological blockade of SK channels, suggesting a novel target for the treatment of attentional impairments in $\mathrm{AD}$.

The TgCRND8 mouse model is a widely used model of disease that recapitulates several key neuropathological and cognitive features of $\mathrm{AD}$ (Chishti et al., 2001; Webster et al., 2014), including attention deficits (Romberg et al., 2013b). Because TgCRND8 mice harbor APP mutations without disruptions to other genetic loci of $\mathrm{AD}$ vulnerability, namely the tau and presenilin genes (Selkoe, 2001; Goedert and Spillantini, 2006), these previously documented attentional impairments appear related to the overexpression of APP, aberrant APP processing, and/or the production of $\beta$-amyloid $(\mathrm{A} \beta)$ pathology. The disruption of the cholinergic excitation of PFC layer 6 neurons described here is a plausible proximate cause for the attention deficits observed in TgCRND8 mice. These animals display impairments on the five- choice serial reaction time task (for review, see Bari et al., 2008; Romberg et al., 2013b), an attentional task that requires cholinergic modulation of the deep layer PFC neurons for optimal performance (Bailey et al., 2010; Guillem et al., 2011). The PFC constitutes an important hub for higher cognitive function (Duncan and Owen, 2000; Buckner et al., 2009; Cole et al., 2013; Sporns, 2014), and its neuromodulation exerts powerful influences on the brain as a whole. The ACh released in the PFC during attention tasks (Parikh et al., 2007) robustly and directly excites the deep cortical layers (Kassam et al., 2008; Poorthuis et al., 2013; Proulx et al., 2014a) in a manner consistent with the sustained firing necessary for attention and other executive functions (Funahashi, 2001; Hasselmo and Sarter, 2011; Ikkai and Curtis, 2011; Zhou et al., 2011). The cholinergic modulation of PFC layer 6 would be especially important in this regard given its dense corticothalamic feedback projections and local influence over the activity of the cortical column (Thomson, 2010; Olsen et al., 2012; Kim et al., 2014; Proulx et al., 2014a). It will 
A +200 nM apamin
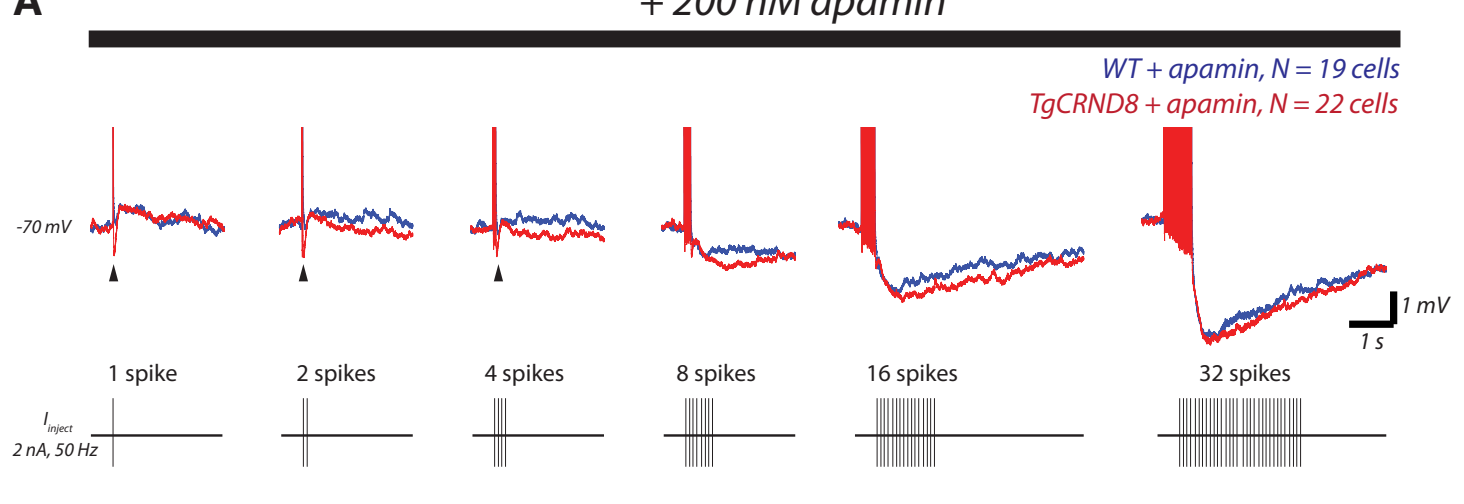

$W T+$ apamin, $N=19$ cells
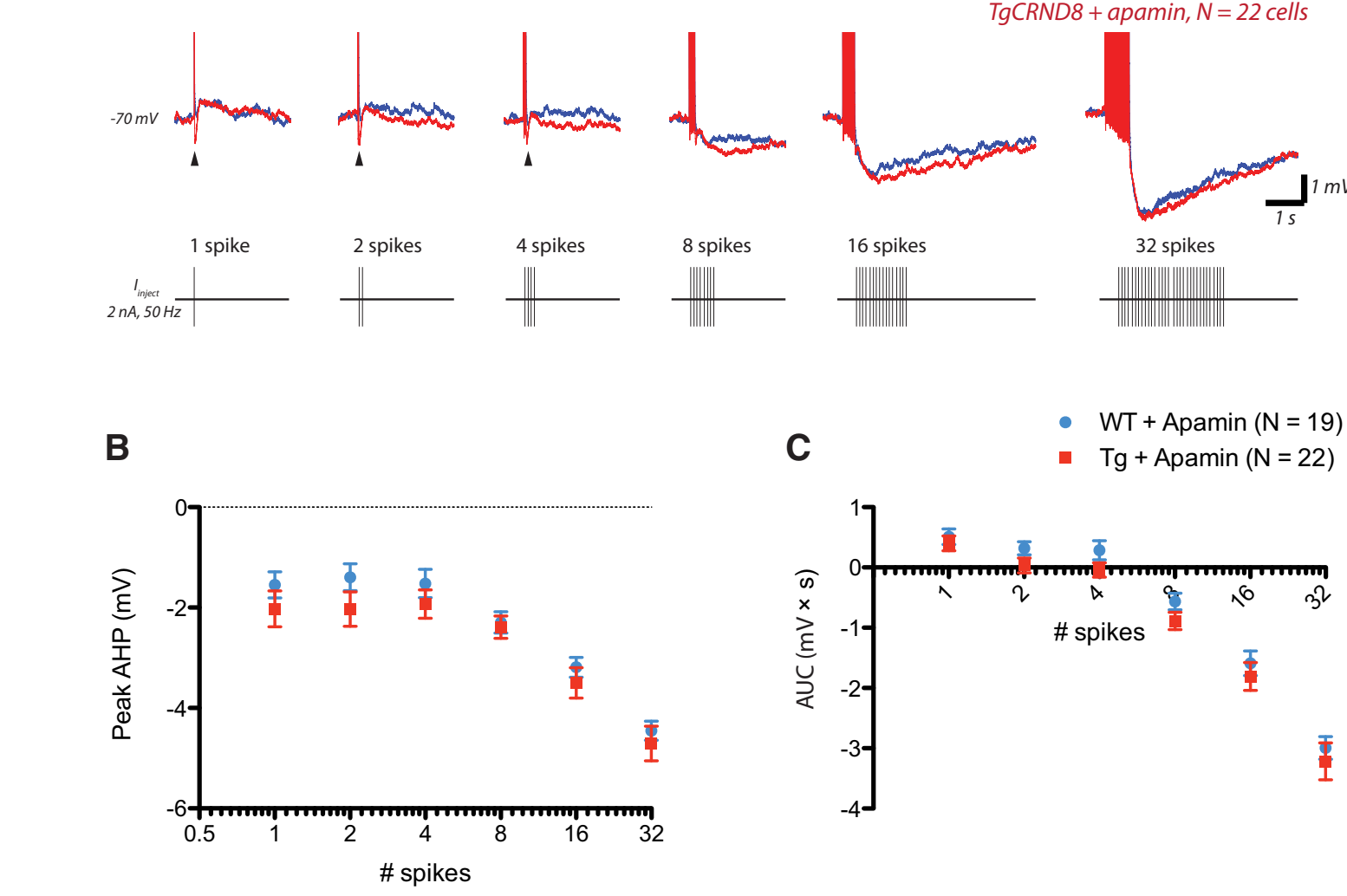

Figure 6. Enhanced AHPs in TgCRND8 neurons result from a greater SK contribution. $A, 0$ verlay of the postburst AHPs elicited by the spike burst protocol in the presence of apamin (200 $\mathrm{nm}$ ) in WT (blue, $n=19$ cells) and TgCRND8 (red, $n=22$ cells) mice. $B$, C, Measurements of the peak AHP (two-way ANOVA, effect of genotype, $F_{(1,234)}=4.90, p=0.03$ ) and postburst area (two-way ANOVA, effect of genotype, $F_{(1,234)}=5.94, p=0.02$ ). Apamin was most effective at normalizing the post-burst AHP in TgCRND8 in which the genotype difference was most pronounced (WT ${ }_{\text {apamin }}$ Vs $\operatorname{TgCRND8}$ apamin , peak AHP $\left.100-500 \mathrm{~ms}^{\prime} F_{(1,234)}=0.04, p=0.84 ; \mathrm{AUC}_{100-500 \mathrm{~ms}^{\prime}} F_{(1,234)}=0.40, p=0.53\right)$ but reveals a residual, apamin-resistant early AHP in TgCRND8 (1-4 spikes, arrowheads).

be most interesting in future work to determine whether and how the targeted modulation of prefrontal layer 6 pyramidal cell excitability by SK channels can impinge on cognitive performance.

The impairments in cholinergic excitability we document would be exacerbated by previously described cholinergic changes that accompany the progression of AD. Such deficits include the neurodegeneration of the cholinergic cells of the basal forebrain (Davies and Maloney, 1976; Whitehouse et al., 1982), as well as a decrease in the enzymatic activity related to the synthesis and breakdown of ACh (Davies and Maloney, 1976; Perry et al., 1978; Henke and Lang, 1983; Zubenko et al., 1989; Davis et al., 1999; Selkoe, 2001; Auld et al., 2002; DeKosky et al., 2002). In the current study, however, bath application of ACh would circumvent potential differences in endogenous ACh levels between the genotypes, indicating that significant differences in cholinergic responses are observed in the TgCRND8 neurons independently of the disruptions in ACh levels that accompany disease progression. Significant reductions in nicotinic receptor binding have also been documented in the AD brain, and this holds particularly true for the $\alpha 4 \beta 2 *$ nicotinic receptor subtype (Nordberg et al., 1988; Whitehouse et al., 1988; Marutle et al., 1999; Nordberg, 2001; O'Brien et al., 2007; Kendziorra et al., 2011) that is expressed highly in layer 6 PFC (Wada et al., 1989, 1990; Kassam et al., 2008; Alves et al., 2010). There is also some evidence of disrupted functional coupling of excitatory muscarinic receptors to downstream cellular effectors (Jope et al., 1997; Jope, 1999). Fur- thermore, $\mathrm{A} \beta$ peptides can impair both muscarinic (Kelly et al., 1996) and nicotinic (Liu et al., 2001; Pettit et al., 2001) receptor function and indeed interfere with the cholinergic system as a whole (for review, see Auld et al., 2002). It is striking that we found only modest reductions in TgCRND8 ACh currents near resting membrane potential and neither differences in muscarinic or nicotinic currents between the genotypes nor in the level of depolarization achieved. Instead, the greatest difference rested in the degree to which layer 6 cells could sustain firing in response to ACh. The extent to which nicotinic and muscarinic receptors contribute to this threshold effect will be critical to elucidate in future work, particularly in view of the accompanying suprathreshold calcium differences that are reported here.

Cholinergic signaling can alter intracellular calcium levels in a multitude of ways. The subtype of nicotinic receptors that play a prominent role in the excitation of PFC layer 6 cells (Kassam et al., 2008; Tian et al., 2011; Poorthuis et al., 2013) are characterized by unusual calcium permeability (Fucile, 2004; Tapia et al., 2007). Although the $M_{1}$ muscarinic receptors contribute only modestly to the depolarization of PFC layer 6 cells (Tian et al., 2014), they can trigger the release of calcium from intracellular stores (Berridge and Irvine, 1984; Neher et al., 1988; Gulledge and Stuart, 2005; Proulx et al., 2014b). Disruptions in intracellular calcium have been documented in several models of AD (Stutzmann et al., 2004; Stutzmann, 2006; Wykes et al., 2012; Chakroborty and Stutzmann, 2014). Potential contributors suggested to be perturbed in models of $\mathrm{AD}$ include calcium-permeable nic- 

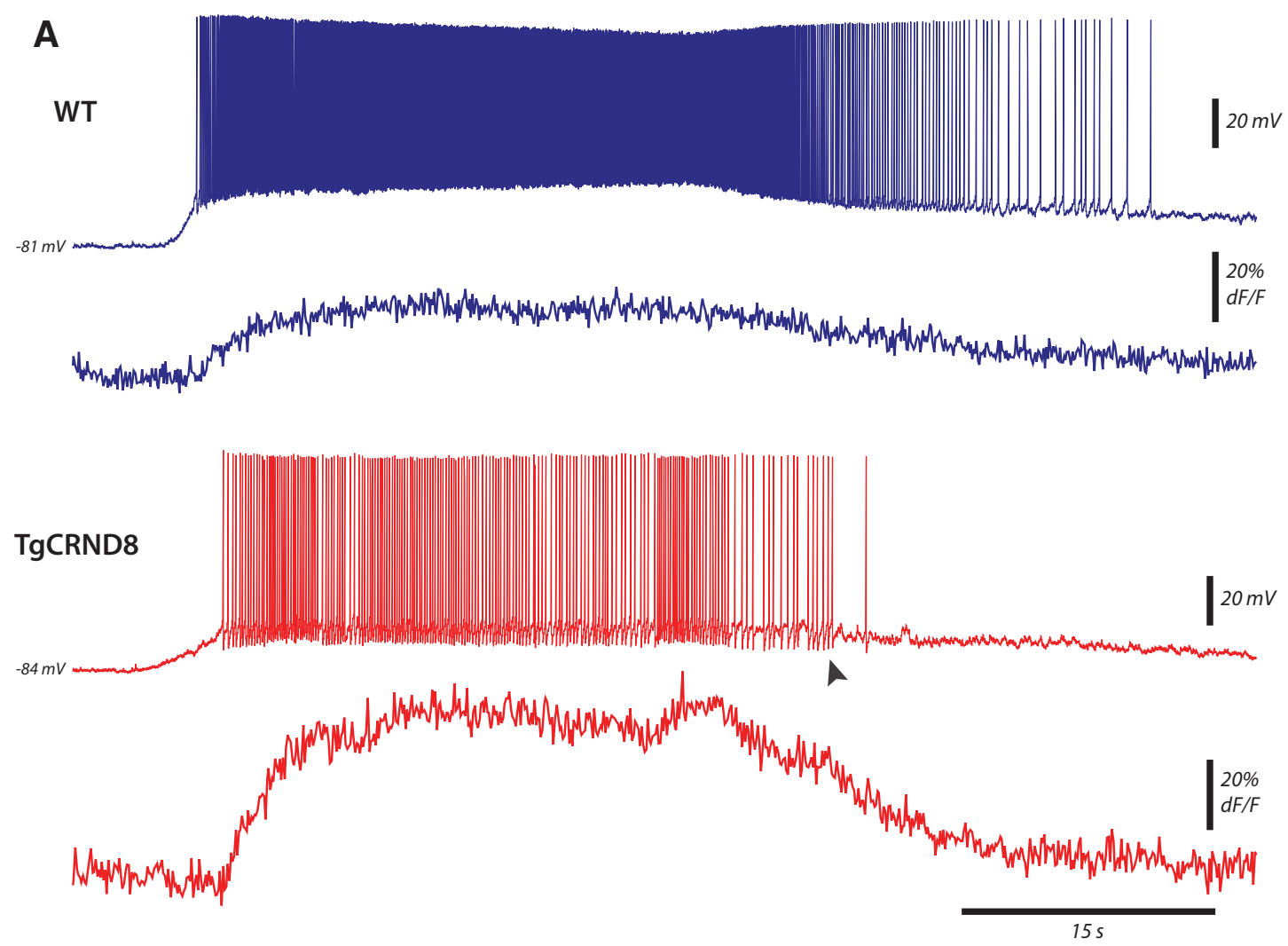

Mean ACh-elicited firing frequency over time

B
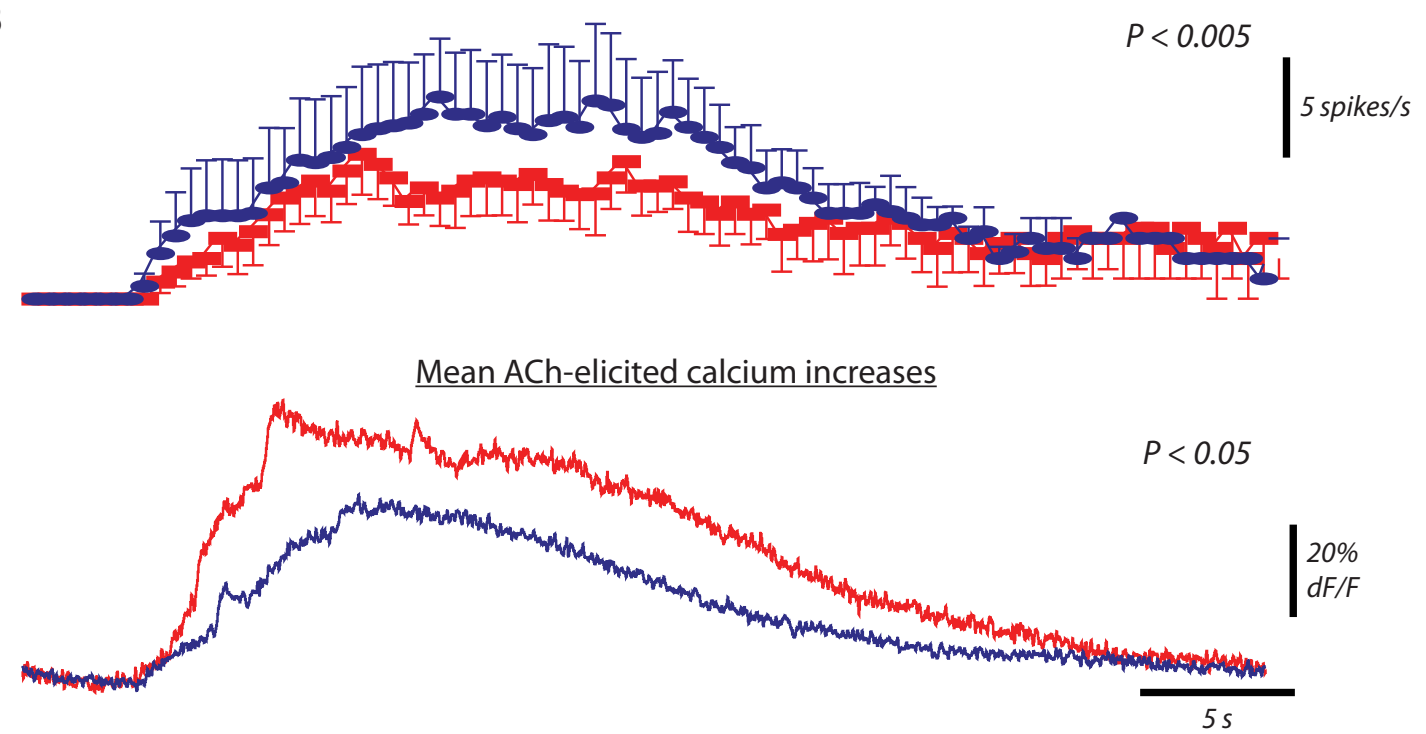

Figure 7. Greater $\mathrm{Ca}^{2+}$ responses accompany ACh-elicited firing in the $\mathrm{TgCRND} 8$. ACh (1 mm, $15 \mathrm{~s}$ ) elicited spiking in eight of nine cells in WT and six of seven in TgCRND8, with calcium increases that were significantly greater in the TgCRND8 cells as detected by the calcium-sensitive dye 0GB-1 (100 $\mu \mathrm{m}$ ). $A$, Example of whole-cell membrane potential (top) and calcium increases (bottom) simultaneously recorded in response to bath application of ACh in WT (top panel) and TgCRND8 (bottom panel). Note the large AHPs in the TgCRND8 trace (arrowhead). $B$, Average number of spikes per seconds (top) and calcium responses (bottom) elicited by ACh in the WT (blue, $n=8$ ) and $\operatorname{TgCRND8}$ (red, $n=6$ cells) cells.

otinic receptors (Liu et al., 2001; Pettit et al., 2001), excitatory muscarinic receptors (Kelly et al., 1996), voltage-gated calcium channels (Wang and Mattson, 2014), calcium-induced calcium release (Stutzmann et al., 2004; Stutzmann, 2006), and extrasensitive NMDA receptors (Shah and Haylett, 2002; Goussakov et al., 2010; Romberg et al., 2012; Wang and Mattson, 2014). Here we find that layer 6 neurons in the TgCRND8 mice do not have aberrant calcium levels at baseline and show only moderate ele- vation in response to strong depolarizing stimuli and, indeed, to cholinergic stimulation below threshold. Instead, the combination of cholinergic stimuli and depolarization is required to bring about strongly elevated intracellular calcium levels. Our data indicate that aberrations in voltage-gated calcium channel and NMDA receptor function may contribute to this suprathreshold effect. It is interesting to note that calcium flux through both voltage-gated calcium channels and NMDA receptors can couple 

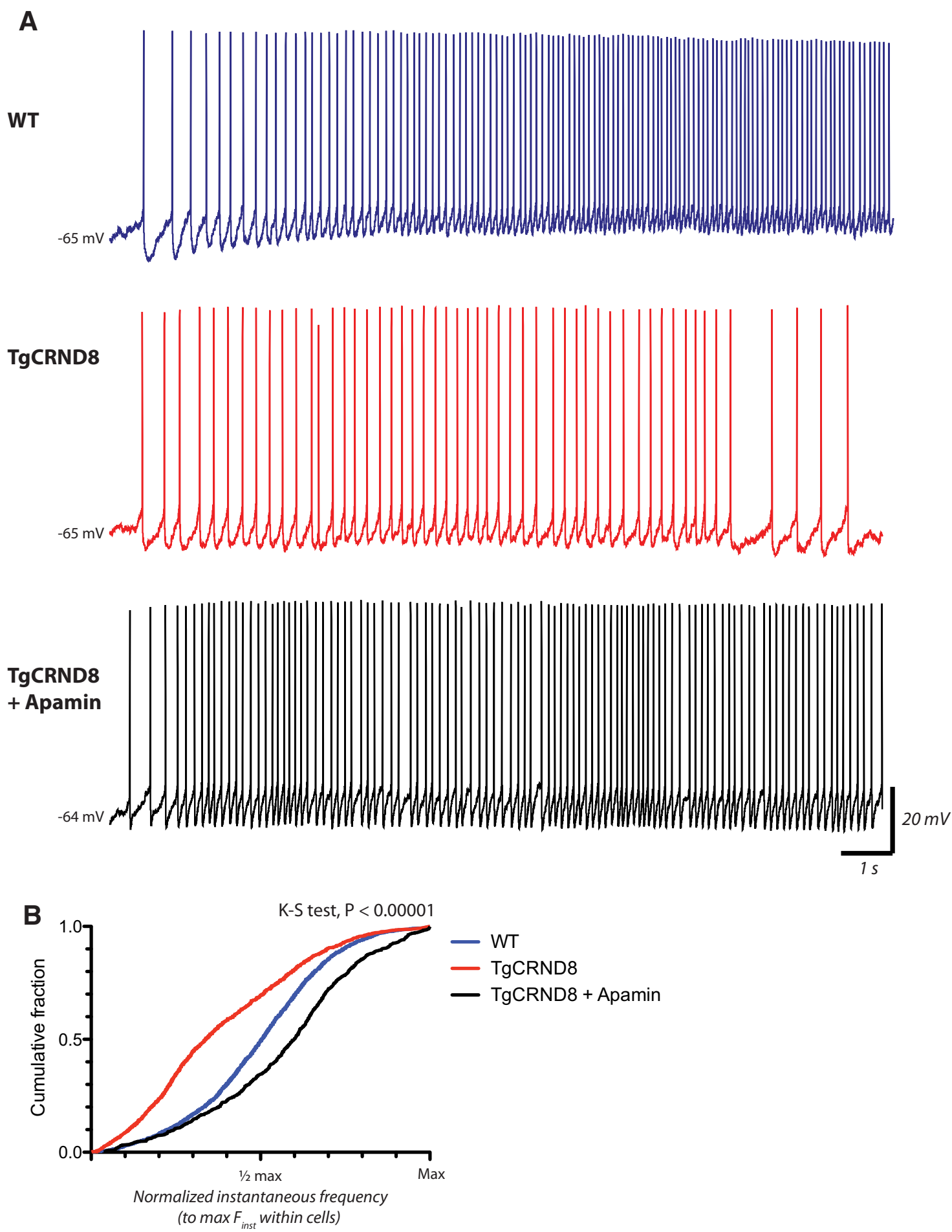

Figure 8. Inhibition of SK improves cholinergic excitability in TgCRND8 mice. $A$, Representative example of cell firing elicited by bath application of $1 \mathrm{~mm} A C h(15 \mathrm{~s})$ in WT (top, blue trace), TgCRND8 (middle, red trace), and a TgCRND8 cell in the presence apamin (bottom, black trace). Traces represent the first $15 \mathrm{~s}$ of ACh-elicited firing. $\boldsymbol{B}$, Apamin induces a rightward shift of the cumulative probability distribution of ACh-elicited firing frequency in $\operatorname{TgCRND8}$ (K-S test, $p<0.00001$; $\operatorname{TgCRND8}$ control, $n=15$ cells, $\operatorname{TgCRND8}+$ Apamin, $n=8$ cells).

to SK channels (Marrion and Tavalin 1998; Wolfart and Roeper, 2002; Ngo-Anh et al., 2005; Giessel and Sabatini, 2010), which could account for the impairments in cholinergic firing of layer 6 TgCRND8 neurons that are documented in the current study. However, much additional work will be necessary to determine the cellular mechanisms underlying suprathreshold calcium responses in the TgCRND8 mice and its subsequent dysregulation of cholinergic firing and whether such an interaction is specific to the cholinergic system remains an open question. Nonetheless, it is clear that the cholinergic stimulation of layer 6 pyramidal cells of the PFC can be regarded as a highly relevant physiological stimulus essential to optimal attentional performance (Bailey et al., 2010; Guillem et al., 2011; Proulx et al., 2014a).

In the major corticothalamic layer, in which modulation by $\mathrm{ACh}$ is essential for optimal attentional function, we have found that there is impaired cholinergic excitability in a mouse model of 
AD. Furthermore, we have found that blockade of the SK class of calcium-activated potassium ion channels significantly restores persistent cholinergic excitability in PFC of TgCRND8. Consistent with this finding, local PFC administration of an SK blocker has been shown to improve executive function (Brennan et al., 2008). Of note, the SK-mediated AHP is modifiable by experience (Disterhoft and Oh, 2006), a modulatory control that appears to be essential for learning. However, the dynamic control of its magnitude, and even its calcium sensitivity, is complex (Bildl et al., 2004; Kramár et al., 2004; Ren et al., 2006; Allen et al., 2007; Giessel and Sabatini, 2010; El-Hassar et al., 2014). Regulation of the SK-mediated AHP by BDNF points to a potential locus of disruption in AD and the TgCRND8 model that would be correlated with early cognitive decline (Peng et al., 2005; Francis et al., 2012). Understanding the regulation of persistent cholinergic excitation in PFC attention circuits is a key step in understanding normal control of executive function and its vulnerability to disruption in AD.

\section{References}

Allen D, Fakler B, Maylie J, Adelman JP (2007) Organization and regulation of small conductance $\mathrm{Ca}^{2+}$-activated $\mathrm{K}^{+}$channel multiprotein complexes. J Neurosci 27:2369-2376. CrossRef Medline

Alves NC, Bailey CDC, Nashmi R, Lambe EK (2010) Developmental sex differences in nicotinic currents of prefrontal layer VI neurons in mice and rats PLoS One 5:e9261. CrossRef

Auld DS, Kornecook TJ, Bastianetto S, Quirion R (2002) Alzheimer's disease and the basal forebrain cholinergic system: relations to beta-amyloid peptides, cognition, and treatment strategies. Prog Neurobiol 68:209245. CrossRef Medline

Baddeley AD, Baddeley HA, Bucks RS, Wilcock GK (2001) Attentional control in Alzheimer's disease. Brain 124:1492-1508. CrossRef Medline

Bailey CD, De Biasi M, Fletcher PJ, Lambe EK (2010) The nicotinic acetylcholine receptor alpha5 subunit plays a key role in attention circuitry and accuracy. J Neurosci 30:9241-9252. CrossRef Medline

Bari A, Dalley JW, Robbins TW (2008) The application of the 5-choice serial reaction time task for the assessment of visual attentional processes and impulse control in rats. Nat Protoc 3:759-767. CrossRef Medline

Bean BP (2007) The action potential in mammalian central neurons. Nat Rev Neurosci 8:451-465. CrossRef Medline

Berridge MJ, Irvine RF (1984) Inositol trisphosphate, a novel second messenger in cellular signal transduction. Nature 312:315-321. CrossRef Medline

Bildl W, Strassmaier T, Thurm H, Andersen J, Eble S, Oliver D, Knipper M, Mann M, Schulte U, Adelman JP, Fakler B (2004) Protein kinase CK2 is coassembled with small conductance $\mathrm{Ca}(2+)$-activated $\mathrm{K}+$ channels and regulates channel gating. Neuron 43:847-858. CrossRef Medline

Brennan AR, Dolinsky B, Vu MA, Stanley M, Yeckel MF, Arnsten AF (2008) Blockade of IP3-mediated SK channel signaling in the rat medial prefrontal cortex improves spatial working memory. Learn Mem 15:93-96. CrossRef Medline

Buckner RL, Sepulcre J, Talukdar T, Krienen FM, Liu H, Hedden T, AndrewsHanna JR, Sperling RA, Johnson KA (2009) Cortical hubs revealed by intrinsic functional connectivity: mapping, assessment of stability, and relation to Alzheimer's disease. J Neurosci 29:1860-1873. CrossRef Medline

Chakroborty S, Stutzmann GE (2014) Calcium channelopathies and Alzheimer's disease: insight into therapeutic success and failures. Eur J Pharmacol 39:83-95. CrossRef Medline

Chishti MA, Yang DS, Janus C, Phinney AL, Horne P, Pearson J, Strome R, Zuker N, Loukides J, French J, Turner S, Lozza G, Grilli M, Kunicki S, Morissette C, Paquette J, Gervais F, Bergeron C, Fraser PE, Carlson GA, George-Hyslop PS, Westaway D (2001) Early-onset amyloid deposition and cognitive deficits in transgenic mice expressing a double mutant form of amyloid precursor protein 695. J Biol Chem 276:21562-21570. CrossRef Medline

Citron M (2010) Alzheimer's disease: strategies for disease modification. Nat Rev Drug Discov 9:387-398. CrossRef Medline

Cole MW, Reynolds JR, Power JD, Repovs G, Anticevic A, Braver TS (2013)
Multi-task connectivity reveals flexible hubs for adaptive task control. Nat Neurosci 16:1348-1355. CrossRef Medline

Dalley JW, Theobald DE, Bouger P, Chudasama Y, Cardinal RN, Robbins TW (2004) Cortical cholinergic function and deficits in visual attentional performance in rats following $192 \mathrm{IgG}$-saporin-induced lesions of the medial prefrontal cortex. Cereb Cortex 14:922-932. CrossRef Medline

Davies P, Maloney AJ (1976) Selective loss of central cholinergic neurons in Alzheimer's disease. Lancet 2:1403. CrossRef Medline

Davis KL, Mohs RC, Marin D, Purohit DP, Perl DP, Lantz M, Austin G, Haroutunian V (1999) Cholinergic markers in elderly patients with early signs of Alzheimer disease. JAMA 281:1401-1406. CrossRef Medline

DeKosky ST, Ikonomovic MD, Styren SD, Beckett L, Wisniewski S, Bennett DA, Cochran EJ, Kordower JH, Mufson EJ (2002) Upregulation of choline acetyltransferase activity in hippocampus and frontal cortex of elderly subjects with mild cognitive impairment. Ann Neurol 51:145-155. CrossRef Medline

Disterhoft JF, Oh MM (2006) Learning, aging and intrinsic neuronal plasticity. Trends Neurosci 29:587-599. CrossRef Medline

Duncan J, Owen AM (2000) Common regions of the human frontal lobe recruited by diverse cognitive demands. Trends Neurosci 23:475-483. CrossRef Medline

El-Hassar L, Simen AA, Duque A, Patel KD, Kaczmarek LK, Arnsten AF, Yeckel MF (2014) Disrupted in schizophrenia 1 modulates medial prefrontal cortex pyramidal neuron activity through cAMP regulation of transient receptor potential $\mathrm{C}$ and small-conductance $\mathrm{K}+$ channels. Biol Psychiatry 76:476-485. CrossRef Medline

Faber ES, Sah P (2003) Calcium-activated potassium channels: multiple contributions to neuronal function. Neuroscientist 9:181-194. CrossRef Medline

Francis BM, Kim J, Barakat ME, Fraenkl S, Yücel YH, Peng S, Michalski B, Fahnestock M, McLaurin J, Mount HT (2012) Object recognition memory and BDNF expression are reduced in young TgCRND8 mice. Neurobiol Aging 33:555-563. CrossRef Medline

Fucile S (2004) Ca2 + permeability of nicotinic acetylcholine receptors. Cell Calcium 35:1-8. CrossRef Medline

Funahashi S (2001) Neuronal mechanisms of executive control by the prefrontal cortex. Neurosci Res 39:147-165. CrossRef Medline

Funahashi S, Bruce CJ, Goldman-Rakic PS (1989) Mnemonic coding of visual space in the monkey's dorsolateral prefrontal cortex. J Neurophysiol 61:331-349. Medline

Giessel AJ, Sabatini BL (2010) M1 Muscarinic receptors boost synaptic potentials and calcium influx in dendritic spines by inhibiting postsynaptic SK channels. Neuron 68:936-947. CrossRef Medline

Goedert M, Spillantini MG (2006) A century of Alzheimer's disease. Science 314:777-781. CrossRef Medline

Goussakov I, Miller MB, Stutzmann GE (2010) NMDA-Mediated Ca ${ }^{2+}$ influx drives aberrant ryanodine receptor activation in dendrites of young Alzheimer's disease mice. J Neurosci 30:12128-12137. CrossRef Medline

Grady CL, Haxby JV, Horwitz B, Sundaram M, Berg G, Schapiro M, Friedland RP, Rapoport SI (1988) Longitudinal study of the early neuropsychological and cerebral metabolic changes in dementia of the Alzheimer type. J Clin Exp Neuropsychol 10:576-596. CrossRef Medline

Guillem K, Bloem B, Poorthuis RB, Loos M, Smit AB, Maskos U, Spijker S, Mansvelder HD (2011) Nicotinic acetylcholine receptor beta2 subunits in the medial prefrontal cortex control attention. Science 333:888-891. CrossRef Medline

Gulledge AT, Stuart GJ (2005) Cholinergic inhibition of neocortical pyramidal neurons. J Neurosci 25:10308-10320. CrossRef Medline

Gulledge AT, Bucci DJ, Zhang SS, Matsui M, Yeh HH (2009) M1 Receptors mediate cholinergic modulation of excitability in neocortical pyramidal neurons. J Neurosci 29:9888-9902. CrossRef Medline

Hasselmo ME, Sarter M (2011) Modes and models of forebrain cholinergic neuromodulation of cognition. Neuropsychopharmacology 36:52-73. CrossRef Medline

Henke H, Lang W (1983) Cholinergic enzymes in neocortex, hippocampus and basal forebrain of non-neurological and senile dementia of Alzheimer-type patients. Brain Res 267:281-291. CrossRef Medline

Ikkai A, Curtis CE (2011) Common neural mechanisms supporting spatial working memory, attention and motor intention. Neuropsychologia 49: 1428-1434. CrossRef Medline

Jope RS (1999) Cholinergic muscarinic receptor signaling by the phospho- 
inositide signal transduction system in Alzheimer's disease. J Alzheimers Dis 1:231-247. Medline

Jope RS, Song L, Powers RE (1997) Cholinergic activation of phosphoinositide signaling is impaired in Alzheimer's disease brain. Neurobiol Aging 18:111-120. CrossRef Medline

Kandel ER, Spencer WA (1961) Electrophysiology of hippocampal neurons. II. After-potentials and repetitive firing. J Neurophysiol 24:243-259. Medline

Kassam SM, Herman PM, Goodfellow NM, Alves NC, Lambe EK (2008) Developmental excitation of corticothalamic neurons by nicotinic acetylcholine receptors. J Neurosci 28:8756-8764. CrossRef Medline

Kelly JF, Furukawa K, Barger SW, Rengen MR, Mark RJ, Blanc EM, Roth GS, Mattson MP (1996) Amyloid beta-peptide disrupts carbachol-induced muscarinic cholinergic signal transduction in cortical neurons. Proc Natl Acad Sci U S A 93:6753-6758. CrossRef Medline

Kendziorra K, Wolf H, Meyer PM, Barthel H, Hesse S, Becker GA, Luthardt J, Schildan A, Patt M, Sorger D, Seese A, Gertz HJ, Sabri O (2011) Decreased cerebral $\alpha 4 \beta 2 *$ nicotinic acetylcholine receptor availability in patients with mild cognitive impairment and Alzheimer's disease assessed with positron emission tomography. Eur J Nucl Med Mol Imaging 38: 515-525. CrossRef Medline

Kim J, Matney CJ, Blankenship A, Hestrin S, Brown SP (2014) Layer 6 corticothalamic neurons activate a cortical output layer, layer 5 a. J Neurosci 34:9656-9664. CrossRef Medline

Kramár EA, Lin B, Lin CY, Arai AC, Gall CM, Lynch G (2004) A novel mechanism for the facilitation of theta-induced long-term potentiation by brain-derived neurotrophic factor. J Neurosci 24:5151-5161. Medline

Liu Q, Kawai H, Berg DK (2001) beta-Amyloid peptide blocks the response of alpha 7-containing nicotinic receptors on hippocampal neurons. Proc Natl Acad Sci U S A 98:4734-4739. CrossRef Medline

Marrion NV, Tavalin SJ (1998) Selective activation of $\mathrm{Ca}^{2+}$-activated $\mathrm{K}^{+}$ channels by co-localized $\mathrm{Ca}^{2+}$ channels in hippocampal neurons. Nature 395:900-905. CrossRef Medline

Marutle A, Warpman U, Bogdanovic N, Lannfelt L, Nordberg A (1999) Neuronal nicotinic receptor deficits in Alzheimer patients with the Swedish amyloid precursor protein 670/671 mutation. J Neurochem 72:11611169. CrossRef Medline

Neher E, Marty A, Fukuda K, Kubo T, Numa S (1988) Intracellular calcium release mediated by two muscarinic receptor subtypes. FEBS Lett 240: 88-94. CrossRef Medline

Ngo-Anh TJ, Bloodgood BL, Lin M, Sabatini BL, Maylie J, Adelman JP (2005) SK channels and NMDA receptors form a $\mathrm{Ca}^{2+}$-mediated feedback loop in dendritic spines. Nat Neurosci 8:642-649. CrossRef Medline

Nordberg A (2001) Nicotinic receptor abnormalities of Alzheimer's disease: therapeutic implications. Biol Psychiatry 49:200-210. CrossRef Medline

Nordberg A, Adem A, Hardy J, Winblad B (1988) Change in nicotinic receptor subtypes in temporal cortex of Alzheimer brains. Neurosci Lett 86:317-321. CrossRef Medline

O’Brien JT, Colloby SJ, Pakrasi S, Perry EK, Pimlott SL, Wyper DJ, McKeith IG, Williams ED (2007) Alpha4beta2 nicotinic receptor status in Alzheimer's disease using 123I-5IA-85380 single-photon-emission computed tomography. J Neurol Neurosurg Psychiatry 78:356-362. CrossRef Medline

Olsen SR, Bortone DS, Adesnik H, Scanziani M (2012) Gain control by layer six in corticalcircuits of vision. Nature 483:47-52. CrossRef Medline

Parikh V, Kozak R, Martinez V, Sarter M (2007) Prefrontal acetylcholine release controls cue detection on multiple timescales. Neuron 56:141154. CrossRef Medline

Peng S, Wuu J, Mufson EJ, Fahnestock M (2005) Precursor form of brainderived neurotrophic factor and mature brain-derived neurotrophic factor are decreased in the pre-clinical stages of Alzheimer's disease. J Neurochem 93:1412-1421. CrossRef Medline

Perry EK, Tomlinson BE, Blessed G, Bergmann K, Gibson PH, Perry RH (1978) Correlation of cholinergic abnormalities with senile plaques and mental test scores in senile dementia. Br Med J 2:1457-1459. CrossRef Medline

Perry RJ, Hodges JR (1999) Attention and executive deficits in Alzheimer's disease. A critical review. Brain 122:383-404. CrossRef Medline

Pettit DL, Shao Z, Yakel JL (2001) beta-Amyloid(1-42) peptide directly modulates nicotinic receptors in the rat hippocampal slice. J Neurosci 21:RC120(1-5). Medline
Poorthuis RB, Bloem B, Schak B, Wester J, de Kock CP, Mansvelder HD (2013) Layer-specific modulation of the prefrontal cortex by nicotinic acetylcholine receptors. Cereb Cortex 23:148-161. CrossRef Medline

Proulx E, Piva M, Tian MK, Bailey CD, Lambe EK (2014a) Nicotinic acetylcholine receptors in attention circuitry: the role of layer VI neurons of prefrontal cortex. Cell Mol Life Sci 71:1225-1244. CrossRef Medline

Proulx É, Suri D, Heximer SP, Vaidya VA, Lambe EK (2014b) Early stress prevents the potentiation of muscarinic excitation by calcium release in adult prefrontal cortex. Biol Psychiatry 76:315-323. CrossRef Medline

Ren Y, Barnwell LF, Alexander JC, Lubin FD, Adelman JP, Pfaffinger PJ, Schrader LA, Anderson AE (2006) Regulation of surface localization of the small conductance $\mathrm{Ca} 2+$-activated potassium channel, Sk2, through direct phosphorylation by cAMP-dependent protein kinase. J Biol Chem 281:11769-11779. CrossRef Medline

Romberg C, McTighe SM, Heath CJ, Whitcomb DJ, Cho K, Bussey TJ, Saksida LM (2012) False recognition in a mouse model of Alzheimer's disease: rescue with sensory restriction and memantine. Brain 135:21032114. CrossRef Medline

Romberg C, Bussey TJ, Saksida LM (2013a) Paying more attention to attention: towards more comprehensive cognitive translation using mouse models of Alzheimer's disease. Brain Res Bull 92:49-55. CrossRef Medline

Romberg C, Horner AE, Bussey TJ, Saksida LM (2013b) A touch screenautomated cognitive test battery reveals impaired attention, memory abnormalities, and increased response inhibition in the TgCRND8 mouse model of Alzheimer's disease. Neurobiol Aging 34:731-744. CrossRef Medline

Sah P (1996) Ca(2+)-activated K+ currents in neurones: types, physiological roles and modulation. Trends Neurosci 19:150-154. CrossRef Medline

Selkoe DJ (2001) Alzheimer's disease: genes, proteins, and therapy. Physiol Rev 81:741-766. Medline

Shah MM, Haylett DG (2002) K+ currents generated by NMDA receptor activation in rat hippocampal pyramidal neurons. J Neurophysiol 87: 2983-2989. Medline

Sporns O (2014) Contributions and challenges for network models in cognitive neuroscience. Nat Neurosci 17:652-660. CrossRef Medline

Stutzmann GE, Caccamo A, LaFerla FM, Parker I (2004) Dysregulated IP3 signaling in cortical neurons of knock-in mice expressing an Alzheimer'slinked mutation in presenilin 1 results in exaggerated Ca2 + signals and altered membrane excitability. J Neurosci 24:508-513. Medline

Stutzmann GE (2006) Enhanced ryanodine receptor recruitment contributes to $\mathrm{Ca}^{2+}$ disruptions in young, adult, and aged Alzheimer's disease mice. J Neurosci 26:5180-5189. CrossRef Medline

Tapia L, Kuryatov A, Lindstrom J (2007) Ca2+ permeability of the (alpha4)3 (beta2)2 stoichiometry greatly exceeds that of (alpha4)2(beta2) 3 human acetylcholine receptors. Mol Pharmacol 71:769-776. CrossRef Medline

Terry AV Jr, Buccafusco JJ (2003) The cholinergic hypothesis of age and Alzheimer's disease-related cognitive deficits: Recent challenges and their implications for novel drug development. J Pharmacol Exp Ther 306:821827. CrossRef Medline

Thomson AM (2010) Neocortical layer 6, a review. Front Neuroanat 4:13. Medline

Tian MK, Bailey CD, De Biasi M, Picciotto MR, Lambe EK (2011) Plasticity of prefrontal attention circuitry: upregulated muscarinic excitability in response to decreased nicotinic signaling following deletion of alpha5 or beta2 subunits. J Neurosci 31:16458-16463. CrossRef Medline

Tian MK, Bailey CD, Lambe EK (2014) Cholinergic excitation in mouse primary vs. associative cortex: region-specific magnitude and receptor balance. Eur J Neurosci 40:2608-2618. CrossRef Medline

Wada E, Wada K, Boulter J, Deneris E, Heinemann S, Patrick J, Swanson LW (1989) Distribution of alpha 2, alpha 3, alpha 4, and beta 2 neuronal nicotinic receptor subunit mRNAs in the central nervous system: a hybridization histochemical study in the rat. J Comp Neurol 284:314-335. CrossRef Medline

Wada E, McKinnon D, Heinemann S, Patrick J, Swanson LW (1990) The distribution of mRNA encoded by a new member of the neuronal nicotinic acetylcholine receptor gene family (alpha 5 ) in the rat central nervous system. Brain Res 526:45-53. CrossRef Medline

Wang Y, Mattson MP (2014) L-type Ca2+ currents at CA1 synapses, but not $\mathrm{CA} 3$ or dentate granule neuron synapses, are increased in $3 \times \mathrm{TgAD}$ 
mice in an age-dependent manner. Neurobiol Aging 35:88-95. CrossRef Medline

Webster SJ, Bachstetter AD, Nelson PT, Schmitt FA, Van Eldik LJ (2014) Using mice to model Alzheimer's dementia: an overview of the clinical disease and the preclinical behavioral changes in 10 mouse models. Front Genet 5:88. CrossRef Medline

Whitehouse PJ, Price DL, Struble RG, Clark AW, Coyle JT, Delon MR (1982) Alzheimer's disease and senile dementia: loss of neurons in the basal forebrain. Science 215:1237-1239. CrossRef Medline

Whitehouse PJ, Martino AM, Wagster MV, Price DL, Mayeux R, Atack JR, Kellar KJ (1988) Reductions in [3H]nicotinic acetylcholine binding in Alzheimer's disease and Parkinson's disease: an autoradiographic study. Neurology 38:720-723. CrossRef Medline
Wolfart J, Roeper J (2002) Selective coupling of T-type calcium channels to SK potassium channels prevents intrinsic bursting in dopaminergic midbrain neurons. J Neurosci 22:3404-3413. Medline

Wykes R, Kalmbach A, Eliava M, Waters J (2012) Changes in the physiology of CA1 hippocampal pyramidal neurons in preplaque CRND8 mice. Neurobiol Aging 33:1609-1623. CrossRef Medline

Zhou X, Qi XL, Douglas K, Palaninathan K, Kang HS, Buccafusco JJ, Blake DT, Constantinidis C (2011) Cholinergic modulation of working memory activity in primate prefrontal cortex. J Neurophysiol 106:2180-2188. CrossRef Medline

Zubenko GS, Moossy J, Martinez AJ, Rao GR, Kopp U, Hanin I (1989) A brain regional analysis of morphologic and cholinergic abnormalities in Alzheimer's disease. Arch Neurol 46:634-638. CrossRef Medline 